Article

\title{
Calcium Phosphate Coating Prepared by Microarc Oxidation Affects hTERT Expression, Molecular Presentation, and Cytokine Secretion in Tumor-Derived Jurkat T Cells
}

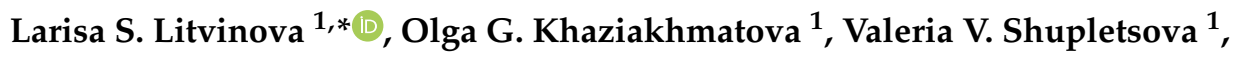 \\ Kristina A. Yurova ${ }^{1}$, Vladimir V. Malashchenko ${ }^{1}$, Egor O. Shunkin ${ }^{1}$, Pavel A. Ivanov ${ }^{1}$, \\ Ekaterina G. Komarova ${ }^{2}$ D , Valentina V. Chebodaeva ${ }^{2}$, Ekaterina D. Porokhova ${ }^{3}$, \\ Elena A. Gereng ${ }^{3}$ and Igor A. Khlusov $1,3,4, *$ D \\ 1 Center for Immunology and Cell Biotechnology, Immanuel Kant Baltic Federal University, \\ 236029 Kaliningrad, Russia; hazik36@mail.ru (O.G.K.); vshupletsova@mail.ru (V.V.S.); \\ kristina_kofanova@mail.ru (K.A.Y.); vvslon@rambler.ru (V.V.M.); egor.shunkin@gmail.com (E.O.S.); \\ ivanov39pavel@gmail.com (P.A.I.) \\ 2 Laboratory of Physics of Nanostructured Biocomposites, Institute of Strength Physics and Materials Science \\ SB RAS, 634055 Tomsk, Russia; katerina@ispms.ru (E.G.K.); vtina5@mail.ru (V.V.C.) \\ 3 Department of Morphology and General Pathology, Siberian State Medical University, 634050 Tomsk, Russia; \\ porohova_e@mail.ru (E.D.P.); e-gereng@mail.ru (E.A.G.) \\ 4 Research School of Chemistry and Applied Biomedical Sciences, National Research Tomsk \\ Polytechnic University, 634050 Tomsk, Russia \\ * Correspondence: larisalitvinova@yandex.ru (L.S.L.); khlusov63@mail.ru (I.A.K.); \\ Tel.: +7-4012-595-595 (ext. 6631) (L.S.L.); +8-3822-901-101 (ext. 1823) (I.A.K.)
}

Received: 25 August 2020; Accepted: 21 September 2020; Published: 27 September 2020

check for updates

\begin{abstract}
Calcium phosphate $(\mathrm{CaP})$ materials are among the best bone graft substitutes, but their use in the repair of damaged bone in tumor patients is still unclear. The human Jurkat $\mathrm{T}$ lymphoblast leukemia-derived cell line (Jurkat $\mathrm{T}$ cells) was exposed in vitro to a titanium (Ti) substrate $\left(10 \times 10 \times 1 \mathrm{~mm}^{3}\right)$ with a bilateral rough (average roughness index $\left.\left(R_{a}\right)=2-5 \mu \mathrm{m}\right) \mathrm{CaP}$ coating applied via the microarc oxidation (MAO) technique, and the morphofunctional response of the cells was studied. Scanning electron microscopy (SEM), X-ray diffraction (XRD), and energy dispersive X-ray spectroscope (EDX) analyses showed voltage-dependent (150-300 V) growth of structural ( $R_{a}$ index, mass, and thickness) and morphological surface and volume elements, a low $\mathrm{Ca} / \mathrm{P}_{\mathrm{aT}}$ ratio (0.3-0.6), and the appearance of crystalline phases of $\mathrm{CaHPO}_{4}$ (monetite) and $\beta-\mathrm{Ca}_{2} \mathrm{P}_{2} \mathrm{O}_{7}$ (calcium pyrophosphate). Cell and molecular reactions in 2-day and 14-day cultures differed strongly and correlated with the $R a$ values. There was significant upregulation of $h T E R T$ expression (1.7-fold), IL-17 secretion, the presentation of the activation antigens CD25 (by 2.7\%) and CD95 (by 5.15\%) on CD4 ${ }^{+}$cells, and 1.5-2-fold increased cell apoptosis and necrosis after two days of culture. Hyperactivation-dependent death of $\mathrm{CD}^{+}$cells triggered by the surface roughness of the CaP coating was proposed. Conversely, a 3.2-fold downregulation in hTERT expression increased the percentages of $\mathrm{CD}^{+}$cells and their $\mathrm{CD}^{+} 5^{+}$subset (by 15.5\% and $22.9 \%$, respectively) and inhibited the secretion of 17 of 27 test cytokines/chemokines without a reduction in Jurkat $\mathrm{T}$ cell survival after 14 days of coculture. Thereafter, cell hypoergy and the selection of an $h T E R T$-independent viable CD4 ${ }^{+}$subset of tumor cells were proposed. The possible role of negative zeta potentials and $\mathrm{Ca}^{2+}$ as effectors of $\mathrm{CaP}$ roughness was discussed. The continuous (2-14 days) 1.5-6-fold reductions in the secretion of vascular endothelial growth factor (VEGF) by tumor cells correlated with the $R_{a}$ values of microarc $\mathrm{CaP}$-coated Ti substrates seems to limit surgical stress-induced metastasis of lymphoid malignancies.
\end{abstract}


Keywords: titanium substrate; $\mathrm{CaP}$ roughness; surface electrostatic and electrokinetic potentials; cell behavior in vitro; correlations

\section{Introduction}

Calcium phosphate $(\mathrm{CaP})$ materials are among the best bone graft substitutes because they promote rapid bone formation and remodeling within their volume and on their surface and may ensure bone healing within a year. Despite these achievements, the mechanisms behind the CaP features (structure, size, and solubility) that induce healthy bone formation are still incompletely understood [1]. Moreover, the human population is aging, and the rates of osteoporosis (up to $30 \%$ of hospital beds) [1] and cancer patients are escalating. Clinical success was already achieved with CaP-coated metallic implants in the 1980-90s [2].

Plasma electrolytic or microarc oxidation (MAO) is one the most applicable techniques to prepare metal-oxide and CaP coatings [3-6] that can be relatively easily improved and innovate traumatological and orthopedic practice. We have previously detected the synthetic microterritories in microarc CaP coating which promote osteogenic differentiation and maturation of mesenchymal stem cells in vitro [7]. However, a question still remains: Are CaP materials a good choice for repairing damaged bone in tumor patients?

The CaP materials are used to treat bone cysts [8] caused by an oncotomy in particular. The key problem is to overcome the minimal residual disease and to kill malignant mesenchymal or leukemic cells in the highly vascularized bone and red marrow (RM) areas [9]. Bone and RM could create a very efficient niche to support the survival and proliferation of the healthy and tumor cells [10], including metastatic cancer cells [11]. Aveic et al. (2019) concluded that CaP porous material as a simplified three-dimensional (3D) replica of bone and RM niche provides a mimetic 3D niche suitable for invasive tumor cells [11].

Therefore, scaffold-based strategy is one of the modern platforms to simulate the physical-chemical, mechanical, and structural traits of the extracellular matrix microenvironment (stiffness, topography, elemental and phase composition, solubility, etc.) that is useful for in vitro engineering and studying of solid and non-solid tumors $[12,13]$. There were significant attempts to optimize bone and marrow niche models for leukemic cells [14]. Biodegradable and non-biodegradable polymers, such as poly (l-lactic-co-glycolic acid), polyurethane, poly (methyl- methacrylate), poly (d,l-lactide), poly (caprolactone), and polystyrene, have been used in both in vitro $[13,15]$ and in vivo [16] models to investigate acute myeloid leukemia and multiple myeloma, mainly. According to unresolved questions in humanized tumor ECM modeling reviewed in [13], artificial material should be as biomimetic as possible. Certainly, CaP-based approaches must contribute main efforts for bone and RM engineering in pathological conditions. However, several publications were devoted to a CaP-based technique to control a behavior of human malignant hematopoietic cells [11,17].

Hereafter, malignant cell lines, such as MG-63 osteoblast-like cells [18] and human leukemic T lymphoblast-like cell line (Jurkat T cells) $[19,20]$, are often used for orthopedic material testing to develop rough titanium (Ti) and $\mathrm{TiO}_{2}$ surfaces. Jurkat $\mathrm{T}$ cells were specifically obtained to screen calcium signaling in T cell receptor (TCR)-CD3-CD4 activation [21] and triggered cell-cycle progression in resting $\mathrm{T}$ cell populations [22]. Therefore, these cells may be applicable targets for testing the effect of $\mathrm{CaP}$ on leukemic cells. Numerous in vitro studies describing mainly short-term (typically no more than $72 \mathrm{~h}$ ) cultures $[19,20,23-26]$ provide incomplete information about malignant cell progression and interactions with artificial materials designed for longitudinal contact with the body. Only single articles described a long-term influence of certain CaP materials on some types of cancer cells. For example, the study in [11] explored a behavior (proliferation, survival, and differentiation) of neuroblastoma cells metastasized to bone and RM and contacted in vitro for 10 days with the $\beta$-tricalcium phosphate porous scaffolds. 
Hence, this investigation aimed to examine the short-term (2 days) and prolonged (14 days) in vitro morphofunctional reactions of Jurkat $\mathrm{T}$ cells induced by a rough $\mathrm{CaP}$ coating prepared via the MAO method on a Ti substrate.

\section{Materials and Methods}

\subsection{Sample Preparation and MAO Treatment Procedures}

Pure, commercial Ti (Grade 2) billets with a thickness of $1.0 \mathrm{~mm}$ (VSMPO-AVISMA Corp., Verkhnaya Salda, Russia) were used as the initial material. The Ti was cut into plates with a size of $10 \times 10 \mathrm{~mm}^{2}$ and polished with SiC paper with a grade ranging from P180 to P2000. Then, the samples were ultrasonically cleaned (Elmasonic S, Elma Schmidbauer GmbH, Singen, Germany) in distilled water and ethanol for $10 \mathrm{~min}$ and dried in air.

Microarc 3.0 installation (ISPMSSB RAS, Tomsk, Russia) was used to carry out the MAO process [27]. The installation system consisted of a pulsed DC power supply, an electrolytic bath with a water-cooling system, two electrodes, and a computer to control the process. To synthesize the MAO coatings, the standard electrolyte contained $27 \mathrm{wt} . \% \mathrm{H}_{3} \mathrm{PO}_{4}, 7 \mathrm{wt} . \% \mathrm{CaCO}_{3}, 5 \mathrm{wt} . \%$ nanosized stoichiometric hydroxyapatite (HAp; $\left.\mathrm{Ca}_{10}\left(\mathrm{PO}_{4}\right)_{6}(\mathrm{OH})_{2}\right)$ and distilled water as a balance [28]. The obtained electrolyte suspension was an acidic medium with a $\mathrm{pH}$ of 1-2. The stoichiometric HAp was produced by the mechanochemical method in the AGO-3 planetary mill at the Institute of Solid State Chemistry and Mechanochemistry of SB RAS (Novosibirsk, Russia) as previously described [29].

The unipolar anodic potentiostatic regime at a fixed pulse frequency of $50 \mathrm{~Hz}$, pulse duration of $100 \mu \mathrm{s}$, time of $10 \mathrm{~min}$, and varied voltage from 150 to $300 \mathrm{~V}$ with a step of $50 \mathrm{~V}$ was used as previously described [30].

\subsection{MAO Coating Characterization}

The morphology, structure, and elemental composition of the coatings were examined by scanning electron microscopy (SEM) on a LEO EVO 50 electron microscope (Carl Zeiss, Oberkochen, Stuttgart, Germany) equipped with an energy dispersive X-ray spectroscope (EDX, INCA, Oxford Instruments, High Wycombe, UK). EDX microanalysis was performed in the microareas of the coating surface on SEM images. The coating thickness was measured by the secant method using SEM images according to ASTM E1382-9 and DD ENV 1071-5 standard protocols.

The phase composition was determined with X-ray diffraction (XRD, XRD 6000, Shimadzu Corp., Kyoto, Japan) in the angular range of $2 \theta=10-80^{\circ}$ with a scanning step of $0.02^{\circ}$ and counting time of 3 s per step using $\mathrm{Cu} \mathrm{K} \alpha$ radiation. The qualitative phase analysis of the XRD patterns was performed using the ICDD PDF 4+ database.

The mass of the experimental samples before and after MAO treatment was measured using a digital microanalytical balance (GR-202, A\&D Company, Tokyo, Japan). The surface roughness was estimated by the average roughness $\left(R_{a}\right)$ using a contact profilometer (Hommel-Etamic T1000 Basic, Jenoptik, Jena, Germany) [31] because a strong linear correlation between $R_{a}, R_{z}$, and $R_{\max }$ for microarc $\mathrm{CaP}$ coatings was identified [28]. The traverse length and rate of the measured profile were $6 \mathrm{~mm}$ and $0.5 \mathrm{~mm} / \mathrm{s}$, respectively. Ten randomly selected traces were recorded for each specimen.

The equipment for the SEM and EDX studies was provided by the "Nanotech" Common Center for Collective Use (ISPMS SB RAS, Tomsk, Russia), and equipment for XRD analysis was provided by the Tomsk Materials Science Center for Collective Use (National Research Tomsk State University, Tomsk, Russia).

The Eguchi method (the method of lifting the electrode) [32] was used to measure the electrical potential (EP) of the CaP surface under ambient conditions and is described in detail in [28].

The electrokinetic $(\zeta)$ potential was determined at Far East Federal University (Vladivostok, Russia) using a Z-potentiometer for solid surface analysis (SurPASS 3, Anton Paar GmbH, Graz, Austria) in $0.05 \mathrm{M} \mathrm{KCl}$ aqueous solution as described in [33]. 
Before biological analyses, the CaP-coated Ti samples were sterilized using dry heat with a Binder FD53 (Binder GmbH, Tuttlingen, Germany) at $453 \mathrm{~K}$ for $1 \mathrm{~h}$.

\subsection{Cell Culture}

Jurkat T cells were established in 1976 and were isolated from the peripheral blood of a 14-year-old boy with acute lymphoblastic leukemia; these cells were received from the Cell Bank of the Institute of Cytology (Institute of Cytology, Russian Academy of Sciences, Saint Petersburg, Russia) and were cultured at a density of $2 \times 10^{6}$ viable cells per $1.5 \mathrm{~mL}$ of nutrient medium consisting of $90 \%$ RPMI-1640 (Sigma-Aldrich, St. Louis, MO, USA), 10\% inactivated (for $30 \mathrm{~min}$ at $56^{\circ} \mathrm{C}$ ) fetal bovine serum (Sigma-Aldrich, St. Louis, MO, USA), $0.3 \mathrm{mg} / \mathrm{mL}$ L-glutamine (Sigma-Aldrich, St. Louis, MO, USA), and $100 \mathrm{U} / \mathrm{mL}$ penicillin/streptomycin (Sigma-Aldrich, St. Louis, MO, USA). The initial culture consisted of $96 \%$ living, $1 \%$ apoptotic, and 3\% necrotic cells, as shown via flow cytometry (FC) using propidium iodide (PI, Sigma Aldrich, St. Louis, MO, USA) and Annexin V-fluorescein isothiocyanate (FITC) (Abcam, Cambridge, UK) with a MACS Quant FL7 system (Miltenyi Biotec, Bergisch Gladbach, Germany). Each well of a 12-well flat-bottom plate (Orange Scientific, Braine-l'Alleud, Belgium) was filled with one CaP-coated Ti substrate. Six or seven samples per group prepared at different applied voltages were used in 14-day and 2-day cultures, respectively. A cell suspension without test samples was used as a control. The cell cultures were incubated for 2 or 14 days in a humidified atmosphere of $95 \%$ air and $5 \% \mathrm{CO}_{2}$ at $37{ }^{\circ} \mathrm{C}$. While the cells were cultured for 14 days, the nutrient medium was replaced with fresh medium every $3-4$ days.

After culture, the cell suspension was centrifuged at $500 \mathrm{~g}$ for $10 \mathrm{~min}$. The cell pellet was collected to measure $h T E R T$ gene expression, apoptosis, necrosis, and membrane antigen presentation. The cell culture supernatants were used to measure spontaneous and $\mathrm{CaP}$ coating-induced secretion. In vitro manipulation was approved by the Local Ethics Committee of Innovation Park, Immanuel Kant Baltic Federal University, Kaliningrad, Russia (Permission No. 2 from 6 March 2017).

\section{4. hTERT Expression in Cells}

To determine the expression of $h T E R T$ (the telomerase reverse transcriptase gene) in Jurkat $\mathrm{T}$ cells, mRNA was extracted using an RNeasy mini kit (Qiagen, Hilden, Germany) according to the manufacturer's instructions. Total RNA (100 ng) was subsequently reverse-transcribed into cDNA using the QuantiTect reverse transcription kit (Qiagen, Hilden, Germany). hTERT transcription was analyzed via SYBR Green-based quantitative polymerase chain reaction (PCR) as described previously [9]. The results are expressed in arbitrary units as the ratio between the relative amount of hTERT cDNA and the relative amount of $18 \mathrm{~S}$ rRNA cDNA. 18S rRNA cDNA did not exhibit significant changes in expression and was used as a housekeeping gene [34].

\subsection{Measurement of Cell Secretion}

Flow fluorimetry $(\mathrm{FF})$ was performed to measure the concentrations $(\mathrm{pg} / \mathrm{mL})$ of the following human cytokines and chemokines: interleukin (IL)-1 $\beta$, IL-1Ra, IL-2, IL-4, IL-5, IL-6, IL-7, IL-8, IL-9, IL-10, IL-12, IL-13, IL-15, IL-17, tumor necrosis factor alpha (TNF $\alpha$ ), interferon gamma (IFN- $\gamma$ ), basic fibroblast growth factor (FGFb), platelet-derived growth factor (PDGF-BB), vascular endothelial growth factor (VEGF), granulocyte colony-stimulating factor (G-CSF), granulocyte-macrophage colony-stimulating factor (GM-CSF), eotaxin, interferon gamma-induced protein 10 (IP-10; C-X-C motif chemokine 10 (CXCL10), monocyte chemoattractant protein-1 (MCP-1; chemokine (C-C motif) ligand 2 (CCL2), and macrophage inflammatory protein 1 alpha (MIP-1 $\alpha$; CCL3), MIP-1 $\beta$ (CCL4), regulated upon activation, and normal T cell expressed and secreted (RANTES; CCL5). FF was performed with monoclonal antibodies (mAbs) according to the manufacturer's instructions for the cytokine assay system (Bio-Plex Pro Human Cytokine 27-Plex Panel, Bio-Rad, Hercules, CA, USA) using an automated processing system (Bio-Plex Protein Assay System, Bio-Rad, Hercules, CA, USA). 


\subsection{Cell Viability and Immunophenotype Detection}

The fluorescent staining methods more accurately estimate cell viability than trypan blue because ruptured dead or dying Jurkat cells cause an overestimation of the number of live cells when the viability falls below $80 \%$ [35]. Therefore, the in vitro viability of Jurkat T cells was estimated with a MACS Quant flow cytometer (Miltenyi Biotec, Bergisch Gladbach, Germany). After culture, the cells were resuspended in binding buffer, and $5 \mu \mathrm{L}$ of Annexin V-FITC (Abcam, Cambridge, MA, USA) was added to $195 \mu \mathrm{L}$ of the cell suspension. The cells were incubated for $10 \mathrm{~min}$, washed and resuspended in binding buffer. An aliquot of $190 \mu \mathrm{L}$ of the cell suspension was mixed with $10 \mu \mathrm{L}$ of PI solution (Abcam, Cambridge, MA, USA), and the resulting mixture was analyzed by flow cytometry (FC). The percentages of live and dead (apoptotic or necrotic) cells were measured according to the manufacturer's protocol.

Alizarin red S (ARS, Sigma-Aldrich, St. Louis, MO, USA) staining to detect calcification by intracellular diffusion into adherent Jurkat $\mathrm{T}$ cells was performed as recommended by the manufacturer after 14 days of culture.

The cell immunophenotype was analyzed using specific mAbs (see below) according to the manufacturer's instructions. The mAbs were labeled with FITC, allophycocyanin (APC), phycoerythrin (PE), violet blue (VioBlue), or phycoerythrin cyanine 7 (PE-Cy7) (Table 1). Jurkat T cells were washed with phosphate-buffered saline ( $\mathrm{pH}=7.2$ ), and the cell suspension was mixed with a cocktail of mAbs against CD45, CD3, CD4, CD8, and CD25 (Abcam, Cambridge, UK) and CD45RO, CD45RA, CD71, and CD95 (e-Bioscience, San Diego, CA, USA). The algorithm and gating strategy for $\mathrm{CD}_{4} 5^{+} \mathrm{CD}^{+}$ subpopulation cytometry were previously described [20].

Table 1. Monoclonal antibody panel used for the estimation of Jurkat $\mathrm{T}$ cell viability and antigen profiles.

\begin{tabular}{lccccc}
\hline \multirow{2}{*}{ Studied Cell } & \multicolumn{5}{c}{ Fluorochromes and Labeled Monoclonal Antibodies } \\
\cline { 2 - 6 } & FITC & VioBlue & PE & APC & PE-Cy7 \\
\hline \multirow{3}{*}{ Jurkat T cells } & Annexin V & CD45 & CD8 & CD25 & CD4 \\
& CD45RA & CD3 & CD45RO & CD71 & \\
\hline
\end{tabular}

After a $10 \mathrm{~min}$ incubation with the labeled $\mathrm{mAbs}$, the cells were assayed using a MACS Quant flow cytometer (Miltenyi Biotec, Bergisch Gladbach, Germany) according to the manufacturer's protocol. FC results were analyzed using KALUZA analysis software (Beckman Coulter, Brea, CA, USA).

\subsection{Statistical Analysis}

Statistical analyses were conducted using the STATISTICA 13.3 software package for Windows. The mean $(\mathrm{X})$ and standard deviation (SD) or median (Me) and 25\% (Q1) and 75\% (Q3) quartiles were calculated. The normality of the data distribution was determined by the Kolmogorov-Smirnov test. Because of the nonnormal data distribution, the nonparametric Mann-Whitney $U$ test was performed, and statistically significant differences were considered at $p<0.05$. The relationships between the analyzed parameters were established via correlation (Spearman) analyses. Significant relationships were indicated by coefficient $(r)$ values with a significance level greater than $95 \%$.

\section{Results}

\subsection{Morphology, Stucture, and Properties of CaP Coatings}

SEM images represent the surface and cross-section morphology of the CaP coatings deposited by the MAO method under the different applied voltages (Figure 1). As can be seen, the morphology and thickness of the coatings significantly depend on the value of the applied voltage. At the lowest voltage of $150 \mathrm{~V}$, the initial nucleation of hemispherical-shaped structural elements with internal pores on the coating surface occurs (Figure 1a). The thickness of this coating does not exceed $20 \mu \mathrm{m}$ (Figure 1b). 

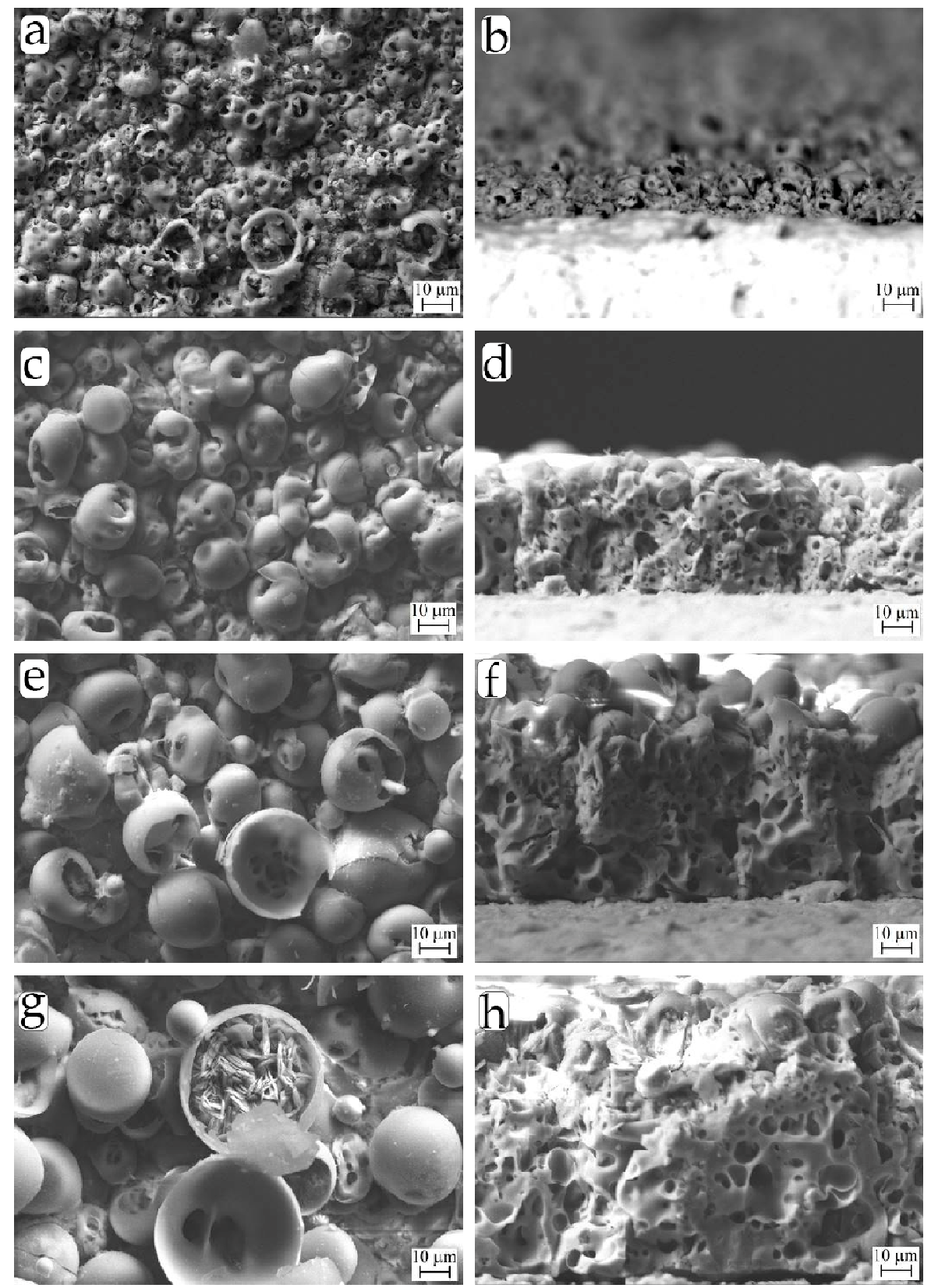

Figure 1. Scanning electron microscopy (SEM) images of the surface (a,c,e,g) and cross-section (b,d,f,h) of the CaP coatings deposited at $150 \mathrm{~V}(\mathbf{a}, \mathbf{b}), 200 \mathrm{~V}(\mathbf{c}, \mathbf{d}), 250 \mathrm{~V}(\mathbf{e}, \mathbf{f})$, and $300 \mathrm{~V}(\mathbf{g}, \mathbf{h})$.

With an increase in the applied voltage from $200 \mathrm{~V}$ to $250 \mathrm{~V}$, spheroidal structural elements (spherulites) and hemispheres with internal pores were completely formed on the coating surface (Figure 1c,e). In addition to internal pores, external pores between the spherulites were observed. Spherulite nucleation occurs by the formation and collapse of a vapor-gas/plasma bubble during the MAO process [36,37]. The coatings deposited at 200-250 V had thicknesses of 50-80 $\mu \mathrm{m}$ (Figure 1d,f).

An increase in the applied voltage from 250 to $300 \mathrm{~V}$ led to an increase in the intensity of microplasma discharges affecting the substrate. As a result, the coating thickness grew from 80 to $100 \mu \mathrm{m}$, the sizes of spherulites and pores increased, and the spherulites were partially destroyed (Figure 1g,h). Moreover, numerous plate-shaped crystals (up to $15 \mu \mathrm{m}$ in length) formed inside the destroyed hemispheres (Figure 1g).

SEM images of the coating cross-sections show that structural elements such as spherulites, hemispheres, and plate-shaped crystals were contained only in the coating surface (Figure $1 \mathrm{~b}, \mathrm{~d}, \mathrm{f}, \mathrm{h}$ ). 
The inner structure of the coatings included multiple branched microsized pores and pore channels (0.5-30 $\mu \mathrm{m}$ in size) inhomogeneously distributed through the coating thickness.

An increase in the applied voltage from 150 to $300 \mathrm{~V}$ led to a linear increase in the CaP coating characteristics $(\mathrm{r}>0.9 ; p<0.001)$. Increases in the thickness from 20 to $100 \mu \mathrm{m}$, mass from 3 to $25 \mathrm{mg}, R_{a}$ from 1.5 to $6.5 \mu \mathrm{m}$, surface porosity from $15 \%$ to $32 \%$, and sizes of the structural elements (the average size of spherulites from 11.0 to $25.3 \mu \mathrm{m}$, the average size of pores from 2.4 to $7.0 \mu \mathrm{m}$ ) occurred (Figure 2).
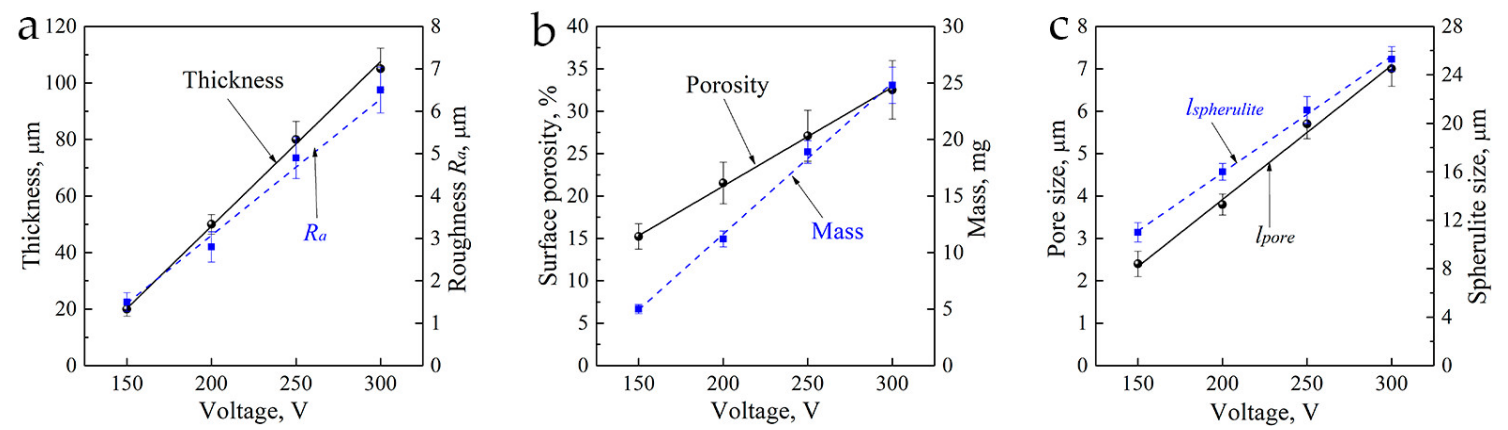

Figure 2. Plots of the coating thickness and roughness, (a) surface porosity and mass, and (b) size of the spheres and pores (c) against the microarc oxidation (MAO)-applied voltage.

XRD studies revealed that the CaP coatings formed at low voltages of 150-250 V were mainly in the X-ray amorphous state as evidenced by the appearance of a diffusive halo at small angles $\left(2 \theta=20-38^{\circ}\right)$ and weak reflections from a single Ti phase (ICDD \#44-1294) of the substrate in the corresponding XRD patterns (Figure 3). An increase in the MAO voltage led to the coating structure transforming from the $\mathrm{X}$-ray amorphous state into the amorphous-crystalline state. XRD patterns of the coatings formed at high voltages of 250-300 V included diffuse halos, as well as reflections of the crystalline phases of dicalcium phosphate anhydrous (DCPA, monetite, $\mathrm{CaHPO}_{4}$ ) (ICDD \#09-0080) and $\beta$-calcium pyrophosphate ( $\beta$-CPP, $\beta-\mathrm{Ca}_{2} \mathrm{P}_{2} \mathrm{O}_{7}$ ) (ICDD \#09-0346) (Figure 3). The intensity of the reflections of these $\mathrm{CaP}$ phases increased with increasing voltage. These XRD data were consistent with the SEM results, indicating the incorporation of plate-shaped crystals in the coatings formed at high voltages of 250-300 V (Figure 1e,g).

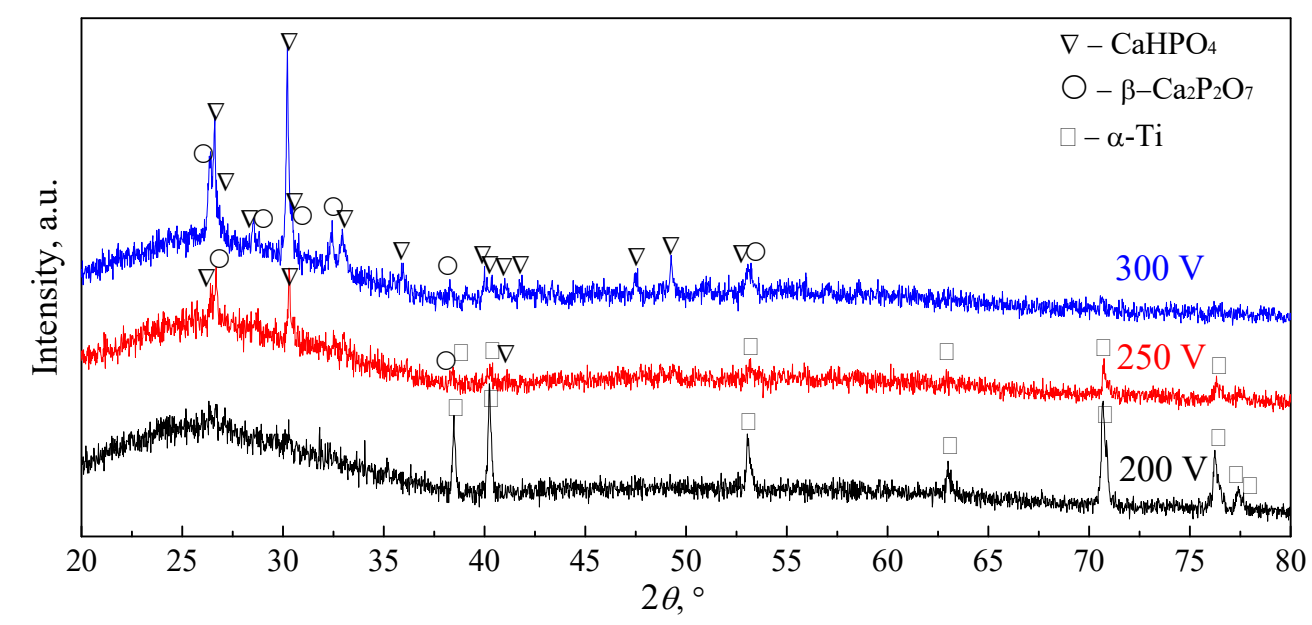

Figure 3. X-ray diffraction (XRD) patterns of the CaP coatings formed at $200 \mathrm{~V}, 250 \mathrm{~V}$, and $300 \mathrm{~V}$.

Figure 4 shows the SEM images and EDX maps of the distribution of the chemical elements (calcium, phosphorus, titanium, and oxygen) over the coating surface. EDX gray-level maps showed that all elements $(\mathrm{Ca}, \mathrm{P}, \mathrm{Ti}$, and $\mathrm{O})$ were distributed fairly uniformly over the surface of the coating formed at low voltages of 150-200 V (Figure 4a). With increasing applied MAO voltage, the Ca content in the 
coatings increased from 4.5 to 7.7 at.\%, and in contrast, the P, Ti, and $\mathrm{O}$ amounts slightly decreased. Increasing the $\mathrm{Ca}$ concentration in the coatings led to an increase in the $\mathrm{Ca} / \mathrm{P}$ atomic ratio from 0.3 to 0.6 . The corresponding maps showed that the increased Ca was mainly concentrated inside the destroyed hemispheres with plate-shaped crystals (these areas are marked by white circles in Figure $4 b, c)$. However, the EDX maps show that the oxygen and phosphorus distribution reproduced the rough topography of the coating $\left(R_{a}=5.0-6.5 \mu \mathrm{m}\right)$.
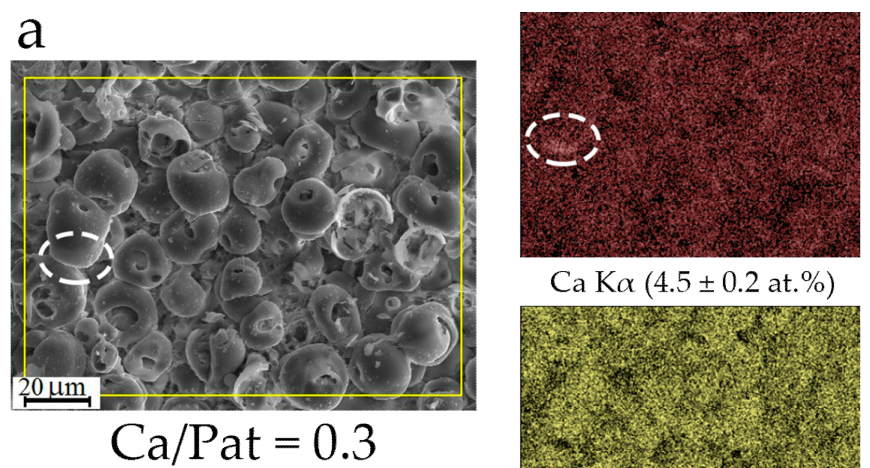

$\mathrm{Ca} \mathrm{K} \alpha(4.5 \pm 0.2$ at. $\%)$

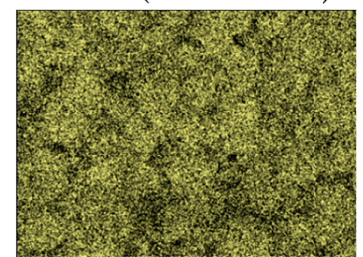

$\operatorname{TiK} \alpha(10.9 \pm 0.3$ at. $\%)$

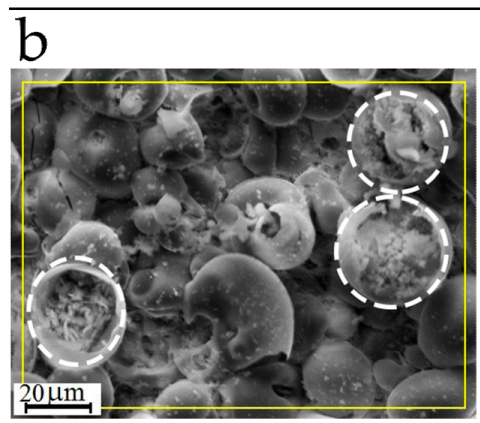

$\mathrm{Ca} / \mathrm{Pat}=0.5$

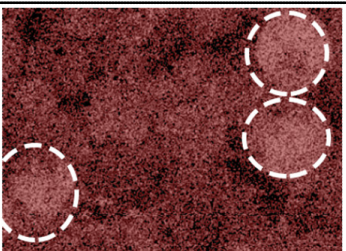

$\mathrm{Ca} \mathrm{K} \alpha(6.9 \pm 0.6$ at. $\%)$

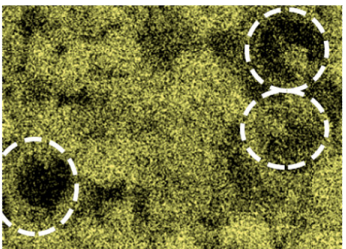

$\operatorname{TiK} \alpha(10.3 \pm 0.4$ at. $\%)$

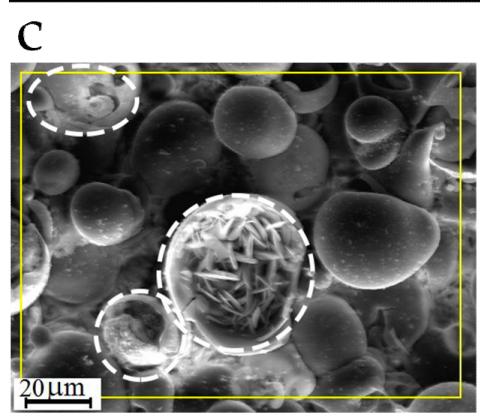

$\mathrm{Ca} / \mathrm{Pat}=0.6$

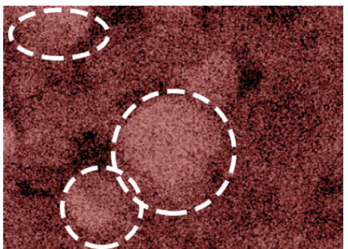

$\mathrm{Ca} \mathrm{K} \alpha(7.7 \pm 0.4$ at. $\%)$

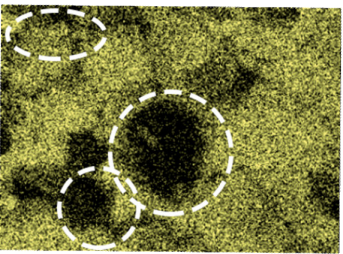

$\operatorname{TiK} \alpha(9.7 \pm 0.5$ at. $\%)$

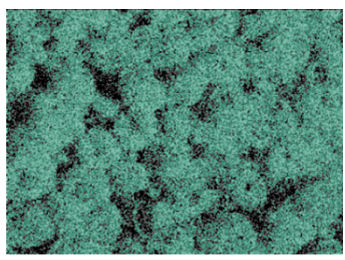

$\mathrm{P} \mathrm{K} \alpha(14.9 \pm 0.5$ at. $\%)$

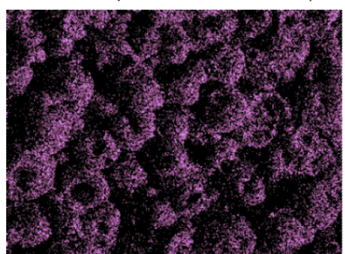

$\mathrm{OK} \alpha(69.7 \pm 3.2$ at. $\%)$

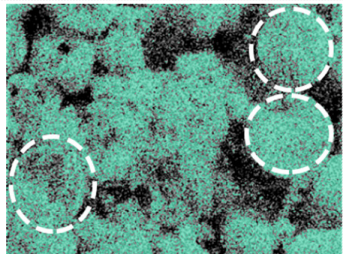

$\mathrm{P} \mathrm{K} \alpha(14.3 \pm 0.6$ at. $\%)$

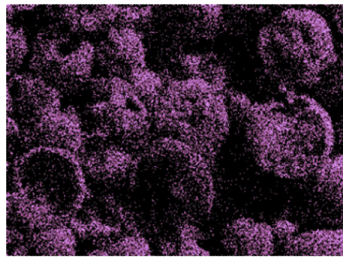

$\mathrm{OK} \alpha(68.8 \pm 2.8$ at. $\%)$

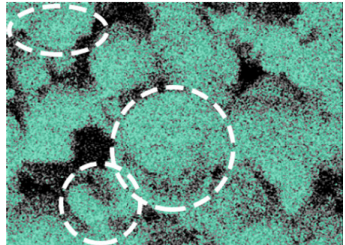

$\mathrm{P} \mathrm{K} \alpha(14.0 \pm 0.7$ at. $\%)$

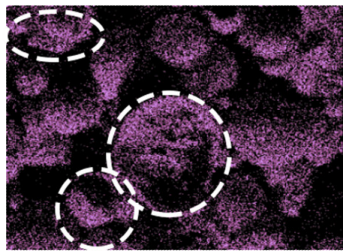

$\mathrm{OK} \alpha(68.6 \pm 2.6$ at. $\%)$

Figure 4. SEM images and EDX gray-level maps of the $\mathrm{Ca}, \mathrm{P}, \mathrm{Ti}$, and $\mathrm{O}$ distributions over the surface of the CaP coatings deposited at $200 \mathrm{~V}$ (a), $250 \mathrm{~V}$ (b), and $300 \mathrm{~V}$ (c).

While CaP coatings obtained by the MAO method are dielectrics, their electrical surface charge is an important feature [28]. The MAO coatings, including the CaP amorphous phase and crystalline 
DCPA and $\beta$-CPP phases, can have both a positive charge in the form of $\mathrm{Ca}^{2+}$ ions and a negative charge in the form of phosphate $\left(\mathrm{PO}_{4}{ }^{3-}\right)$ and hydroxyl $\left(\mathrm{OH}^{-}\right)$groups.

Studies of the integral EP using the Eguchi method showed that all coatings deposited at the applied voltages had a negative electrical charge on their surface. The amplitude of the EP on the coating surface increased with increasing MAO voltage (Figure 5). This effect can be due to the increase in the surface roughness $R_{a}$ from 2.5 to $6.5 \mu \mathrm{m}$ and, consequently, the increase in the free surface area. As a result, the number of negatively charged hydroxyl and phosphate groups increased on the surface of the coatings. These results are consistent with the EDX microanalysis data, which revealed a low $\mathrm{Ca} / \mathrm{P}$ atomic ratio (0.3-0.6 at.\%) in the coatings due to the low calcium content (Figure 4).

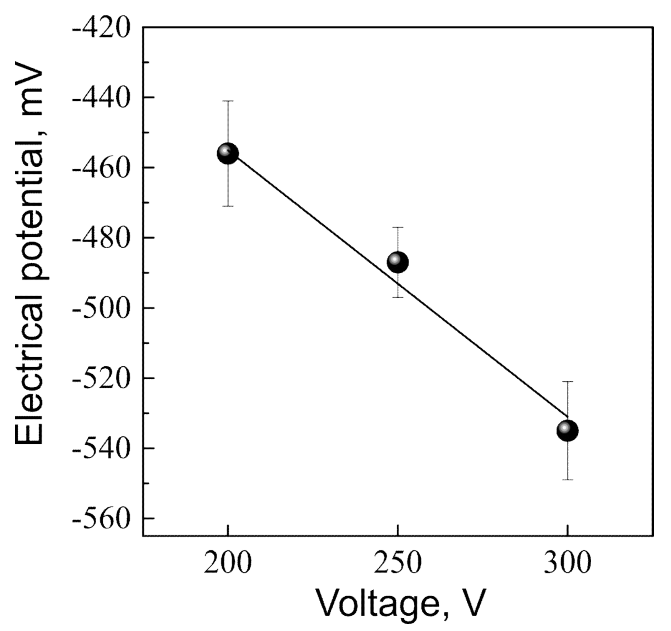

Figure 5. Graph of the electrical potential on the CaP coating surface against the applied MAO voltage.

Thus, we established the range of the applied MAO voltage of 150-300 V provided to form the MAO coatings with a combination of properties required usually for biological applications. The applied voltage of more than $250 \mathrm{~V}$ leads to dramatic decrease in the adhesion strength of thick $\mathrm{CaP}$ coating to Ti substrate [5] that limits its employment in orthopedic practice. Therefore, the range of the applied MAO voltage of $150-250 \mathrm{~V}$ was used to deposit the coatings as follows: $\mathrm{Ca} / \mathrm{P}$ atomic ratio of $0.3-0.5$, thickness of $24-80 \mu \mathrm{m}$, mass of $5-25 \mathrm{mg}$, and roughness index $R_{a}$ of $2.0-5.0 \mu \mathrm{m}$.

\subsection{Biological Properties of $\mathrm{CaP}$ Coating}

In this study, a strong correlation $(r=0.94 ; n=6 ; p<0.005)$ was identified between the $R_{a}$, thickness, and mass values of the microarc CaP coating (Figure 2), which corresponded to our previous data [28]. Therefore, $R_{a}=2.0-5.0 \mu \mathrm{m}$ was mainly used to characterize the relations between the CaP-coated substrates and tumor cell behavior in vitro. Such range of surface roughness is optimal to trigger osteoblastic differentiation and maturation of health stromal cells in vitro [28].

Tumor-derived Jurkat $\mathrm{T}$ cells in contact with the rough CaP coating for 2 days showed a 1.7-fold upregulation in $h T E R T$ expression (Table 2).

No correlations between $R_{a}$ and gene expression were observed. The majority (98\%) of viable Jurkat cells expressed CD3, as expected. $\mathrm{CD}^{+}$cells in the 2-day control culture expressed the $\mathrm{CD}^{+}$ $(95 \%)$ and $\mathrm{CD}^{+} 1^{+}(75 \%)$ profile of CD45RA ${ }^{+}$naïve cells (not activated by the antigen, $92 \%$ ), with subsets of $\mathrm{CD}^{+} \mathrm{T}$ helpers expressing markers of early ( $17 \%$ of the CD25 subset) and late ( $83 \%$ of $\mathrm{CD} 95^{+}$ cells) activation and apoptosis (Table 3). Spontaneous secretory activity in 2-day Jurkat $\mathrm{T}$ cell cultures was low (concentrations of 27 molecules less than $100 \mathrm{pg} / \mathrm{mL}$, Table 4), as previously described [38]. 
Table 2. hTERT expression in Jurkat T cells after different culture times in the presence of a CaP coating on a titanium substrate; $\mathrm{Me}\left(\mathrm{Q}_{1} ; \mathrm{Q}_{3}\right)$.

\begin{tabular}{|c|c|c|c|}
\hline \multicolumn{3}{|c|}{ Bilateral CaP Coating } & \multirow{2}{*}{ hTERT, a.u. } \\
\hline$R_{a}, \mu \mathrm{m}$ & Thickness, $\mu \mathrm{m}$ & Mass, mg & \\
\hline \multicolumn{4}{|c|}{ 2-day culture, $n=7$} \\
\hline $2.88(2.22 ; 3.90)$ & $40.5(24.0 ; 58.0)$ & $12.0(5.2 ; 17.1)$ & $1.66(1.15 ; 1.90)$ \\
\hline \multicolumn{4}{|c|}{ 14-day culture, $n=6$} \\
\hline $2.96(2.14 ; 3.40)$ & $47.5(32.0 ; 62.5)$ & $12.8(9.4 ; 16.9)$ & $-3.26(-5.57 ;-2.34)$ * \\
\hline
\end{tabular}

Note: Here, and below, $n=$ the number of wells (samples) in each group; ${ }^{*}=$ statistical significance $(p<0.05)$ compared with the 2-day culture according to the Mann-Whitney $U$ test; a.u. $=$ arbitrary units; $(-)=$ a suppression of relative gene expression compared with control cell culture without samples; gene measurements were performed in triplicate.

Short-term exposure of the cells to the CaP relief surface increased the expression of CD45RO (from $1.8 \%$ to $7 \%, p<0.04$ ), which was specific to stimulated $\mathrm{T}$ cells (Table 3). This expression was accompanied by the elevated presentation of CD8, which is associated with $\mathrm{T}$ cell differentiation and maturation (from $1.44 \%$ to $3.6 \%, p<0.003$ ), and CD25 (by 2.7\%) and CD95 (by 5.15\%), which are activation antigens on $\mathrm{CD}^{+}$cells. In addition, significant production of IL-17, GM-CSF, and some chemokines (MCP-1, MIP- $1 \alpha$, and MIP-1 $\beta$ ) induced by 2 -day contact with the CaP relief surface occurred. At the same time, there was a 1.5-fold decrease in VEGF levels, while the CaP coating influenced Jurkat $\mathrm{T}$ cells (Table 4). In turn, the viability of Jurkat $\mathrm{T}$ cells diminished significantly, as indicated by 2 - and 1.5-fold increases in cell apoptosis and necrosis, respectively, from short-term contact with the CaP-coated Ti samples (Table 3).

It is highly likely that the expression of genes and CD molecules and cell viability induced by short-term contact with CaP-coated samples suggest well-known [39] hyperactivation-dependent death of $\mathrm{CD}^{+}$cells. We believe that the surface roughness of the CaP coating may be a trigger of the described changes in Jurkat $\mathrm{T}$ cell cultures because of the strong associations between $R_{a}$ indices with increased proportions of necrotic cells $(r=0.95, p<0.001, n=10)$ and the CD4CD95 ${ }^{+}$subset $(r=0.86$, $p<0.001, n=10)$ and the increased IL-17 $(r=0.76, p<0.02, n=9)$ and MCP-1 $(r=0.78, p<0.02, n=9)$ concentrations. Moreover, a close negative relationship $(r=-0.78, p<0.02, n=9)$ between $R_{a}$ and decreased VEGF secretion was determined.

The rough CaP-coated Ti samples caused a 3.2-fold downregulation of hTERT expression in Jurkat $\mathrm{T}$ cells after 14 days of culture (Table 2). Overall, there was a direct correlation between $R_{a}$ values and decreased gene expression $(r=0.88, p<0.03, n=6)$. Long-term contact with the CaP irritant showed increased numbers of $\mathrm{CD} 4^{+}$cells and their $\mathrm{CD}^{+} 5^{+}$subset (by $15.5 \%$ and $22.9 \%$, respectively) and diminished proportions of the $\mathrm{CD}^{+}$and $\mathrm{CD}^{2} 1^{+}$subpopulations of $\mathrm{CD} 45 \mathrm{CD} 3^{+}$cells compared with those of the control 14-day culture (Table 3). The secretion of 17 of the 27 test biomolecules was significantly inhibited (Table 4) without a reduction in Jurkat T cell survival (Table 3). First, the 500-fold and 6-fold downregulated secretion of middle/high levels (more than $0.1 \mathrm{ng} / \mathrm{mL}$ ) [38] of IL-6 and VEGF, respectively, was caused by the CaP coating. Decreased concentrations of 16 of the 17 cytokines, chemokines, and growth factors correlated with increases in the $R_{a}$ index in the range of $r=0.76-0.88$ $(p<0.03, n=11)$. 
Table 3. Viability and immunophenotype of $\mathrm{CD}_{4} 5^{+} \mathrm{CD}^{+}$Jurkat $\mathrm{T}$ cells after different culture periods in the presence of the CaP-coated Ti samples; $\mathrm{Me}\left(\mathrm{Q}_{1}\right.$; $\left.\mathrm{Q}_{3}\right)$.

\begin{tabular}{|c|c|c|c|c|c|c|c|c|c|c|c|c|}
\hline \multicolumn{3}{|c|}{ Bilateral CaP Coating } & \multicolumn{3}{|c|}{ Live or Dead Cells, $\%$} & \multicolumn{7}{|c|}{ Cells Expressing Specific Membrane Markers, $\%$} \\
\hline$R_{a}, \mu \mathrm{m}$ & ess, $\mu \mathrm{m}$ & ass, $\mathrm{mg}$ & able Cells & poptosis & Necrosis & CD4 & CD8 & CD71 & CD45RA & CD45R0 & CD4CD25 & CD4CD95 \\
\hline \multicolumn{13}{|c|}{ (1) Cells on plastic surface (control) after 2-day culture, $n=4$} \\
\hline- & - & - & $\begin{array}{c}84.95 \\
(82.95 ; 86.55)\end{array}$ & $\begin{array}{c}4.05 \\
(2.40 ; 6.0)\end{array}$ & $\begin{array}{c}11.05 \\
(11.0 ; 11.1)\end{array}$ & $\begin{array}{c}95.10 \\
(95.03 ; 95.54)\end{array}$ & $\begin{array}{c}1.44 \\
(0.95 ; 2.22)\end{array}$ & $\begin{array}{c}75.42 \\
(71.90 ; 75.74)\end{array}$ & $\begin{array}{c}91.97 \\
(91.44 ; 92.33)\end{array}$ & $\begin{array}{c}1.81 \\
(1.42 ; 1.96)\end{array}$ & $\begin{array}{c}17.30 \\
(15.61 ; 17.98)\end{array}$ & $\begin{array}{c}83.01 \\
(82.48 ; 83.61)\end{array}$ \\
\hline $\begin{array}{c}2.88 \\
(2.22 ; 3.90)\end{array}$ & $\begin{array}{c}40.5 \\
(24.0 ; 58.0)\end{array}$ & $\begin{array}{c}12.0 \\
(5.2 ; 17.1)\end{array}$ & $\begin{array}{c}76.3 \\
(70.0 ; 77.2) \\
\mathrm{P}_{1}<0.002\end{array}$ & $\begin{array}{c}\text { (2) Cells in ce } \\
8.0 \\
(7.2 ; 10.5) \\
\mathrm{P}_{1}<0.04\end{array}$ & $\begin{array}{c}\text { ntact with th } \\
16.3 \\
(15.6 ; 18.1) \\
\mathrm{P}_{1}<0.001\end{array}$ & $\begin{array}{c}\text { CaP-coated Ti } \\
93.93 \\
(92.39 ; 94.85)\end{array}$ & $\begin{array}{c}\text { samples after } \\
3.60 \\
(3.30 ; 4.96) \\
\mathrm{P}_{1}<0.003\end{array}$ & $\begin{array}{c}\text { 2-day culture, } n \\
\quad 74.54 \\
(72.06 ; 76.62)\end{array}$ & $\begin{array}{l}=7 \\
\quad 81.70 \\
\quad(80.0 ; 89.19) \\
\quad P_{1}<0.02\end{array}$ & $\begin{array}{c}7.08 \\
(2.93 ; 10.11) \\
\mathrm{P}_{1}<0.04\end{array}$ & $\begin{array}{c}20.0 \\
(16.95 ; 22.52) \\
P_{1}<0.02\end{array}$ & $\begin{array}{c}88.18 \\
(84.75 ; 89.59) \\
\mathrm{P}_{1}<0.003\end{array}$ \\
\hline- & - & - & $\begin{array}{c}90.92 \\
(90.18 ; 91.98)\end{array}$ & $\begin{array}{c}\text { (3) Ce } \\
2.88 \\
(2.79 ; 2.99) \\
\text { (4) Cells in co }\end{array}$ & $\begin{array}{c}\text { Is on plastic } \\
6.29 \\
(5.14 ; 6.83) \\
\text { tact with the }\end{array}$ & $\begin{array}{c}\text { urface (control) } \\
62.16 \\
(59.78 ; 62.8) \\
\text { CaP-coated Ti }\end{array}$ & $\begin{array}{c}\text { after 14-day c } \\
2.77 \\
(2.51 ; 3.77) \\
\text { amples after } 1\end{array}$ & $\begin{array}{c}\text { culture, } n=3 \\
98.97 \\
(98.56 ; 99.24)\end{array}$ & $\begin{aligned} & 99.3 \\
( & (99.23 ; 99.34) \\
= & 6\end{aligned}$ & $\begin{array}{c}37.49 \\
(33.42 ; 38.81)\end{array}$ & $\begin{array}{c}27.88 \\
(26.66 ; 29.04)\end{array}$ & $\begin{array}{c}39.03 \\
(38.28 ; 45.24)\end{array}$ \\
\hline $\begin{array}{c}2.96 \\
(2.14 ; 3.40)\end{array}$ & $\begin{array}{c}47.5 \\
(32.0 ; 62.5)\end{array}$ & $\begin{array}{c}12.8 \\
(9.4 ; 16.9)\end{array}$ & $\begin{array}{c}92.32 \\
(89.6 ; 92.79)\end{array}$ & $\begin{array}{c}2.45 \\
(1.81 ; 2.84)\end{array}$ & $\begin{array}{c}5.87 \\
(4.76 ; 7.56)\end{array}$ & $\begin{array}{c}77.65 \\
(77.15 ; 81.11) \\
P_{3}<0.001\end{array}$ & $\begin{array}{c}0.61 \\
(0.41 ; 0.81) \\
\mathrm{P}_{3}<0.001\end{array}$ & $\begin{array}{c}95.92 \\
(95.6 ; 96.35) \\
P_{3}<0.001\end{array}$ & $\begin{array}{c}99.15 \\
(99.12 ; 99.41)\end{array}$ & $\begin{array}{c}39.05 \\
(35.91 ; 41.05)\end{array}$ & $\begin{array}{c}28.77 \\
(27.93 ; 35.32)\end{array}$ & $\begin{array}{c}61.92 \\
(57.27 ; 62.04) \\
P_{3}<0.002\end{array}$ \\
\hline
\end{tabular}

Note: $P_{n}$, significant difference $(<0.05)$ compared with the corresponding group number according to the Mann-Whitney $U$ test. Duplicate probes for each well were measured. 
Table 4. Cytokine concentrations (pg/mL) in the supernatants of Jurkat T cells after different culture times in the presence of the CaP-coated Ti samples; Me (Q1; Q3).

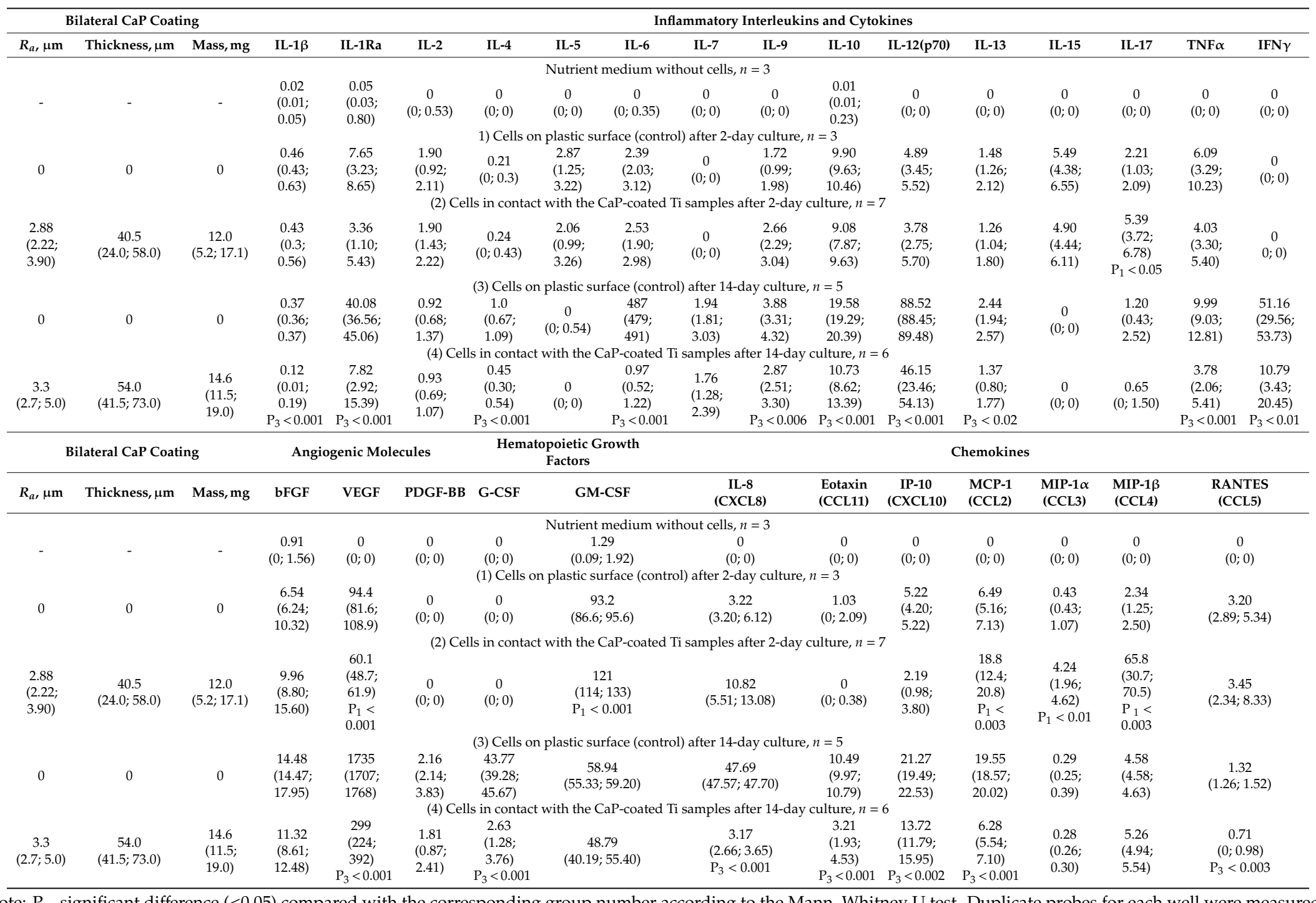


In this context, 14-day contact with the CaP-coated $\mathrm{Ti}$ samples led to unexpected but clear evidence of enhanced ARS staining of nuclei in adherent Jurkat T cells versus unstained tumor cells in control cultures (Figure 6).
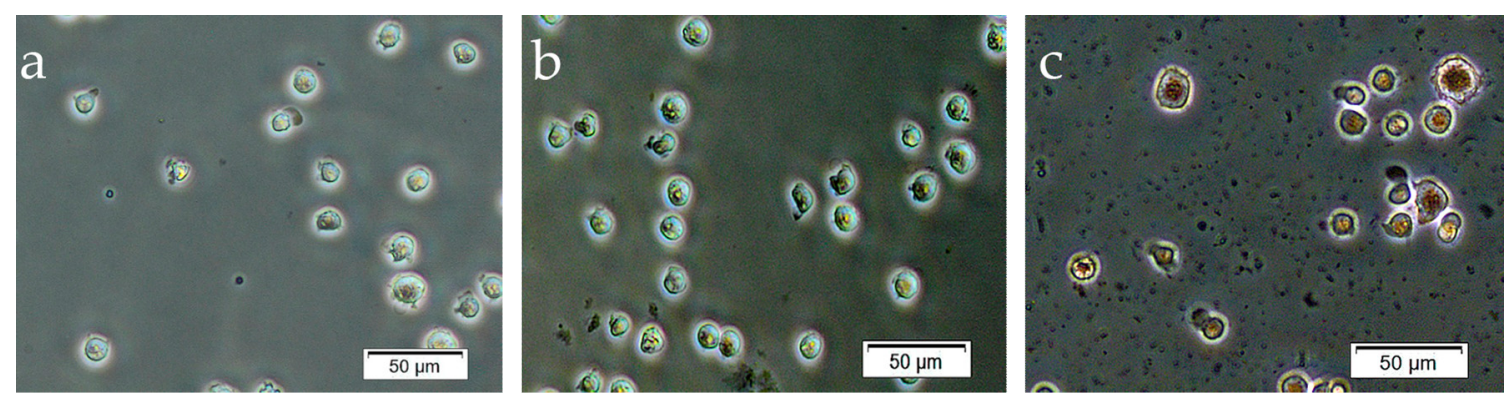

Figure 6. Adherent Jurkat $\mathrm{T}$ cells in 14 days of culture either before (a) or after alizarin red $\mathrm{S}(\mathbf{b}, \mathbf{c})$ staining. (a) Unstained cells; (b) weakly stained nuclei of cells in the control culture without microarc CaP-coated titanium samples; (c) clearly stained nuclei of cells in contact with microarc CaP-coated titanium samples.

Thus, secretory and gene expression hypoergy of Jurkat T cells was observed after prolonged contact with rough $\mathrm{CaP}$-coated $\mathrm{Ti}$ samples, and the close correlation of these effects with the CaP surface roughness index $R_{a}$ was noted.

\section{Discussion}

Overall, SEM, XRD, and EDX analyses (Figures 1-4) showed typical physicochemical properties and some features of the CaP coatings deposited on Ti substrate at voltage ranging from 150-300 V. The features included voltage-dependent growth of structural ( $R_{a}$ index, mass, and thickness) and morphological (spherulites, valleys, and pores) surface and volume elements, calcium content, and the appearance of crystalline phases of $\mathrm{CaHPO}_{4}$ (monetite) and $\beta-\mathrm{Ca}_{2} \mathrm{P}_{2} \mathrm{O}_{7}$ (calcium pyrophosphate). These findings correspond to our previous results [27] and emphasize the technological reproducibility of the MAO method to produce CaP coatings on Ti substrates.

The bioactive microarc CaP coatings have both direct (surface properties) and indirect effects on cells and tissues via the products of their destruction and biodegradation. The EDX analysis showed low $\mathrm{Ca} / \mathrm{P}$ ratios (0.3-0.6) in $\mathrm{CaP}$ coatings (Figure 4). The release of calcium and phosphate ions from the microarc coatings to a solvent medium was episodic for five weeks of in vitro dissolution [27].

Calcium concentrations in a solvent were insignificant (approximately $0.25 \mathrm{mM}$ per week) [27,40] compared with the high $(>2 \mathrm{mM}) \mathrm{Ca}^{2+}$ levels measured in other investigations [41,42] due to ion redeposition (precipitation) on the surface of the microarc CaP-coated Ti samples [27].

An increase in surface roughness is accompanied by an increase in the surface area for dissolution. Enhanced extracellular $\mathrm{Ca}^{2+}$ levels transiently increase intracellular $\mathrm{Ca}^{2+}$ concentrations [43]. Calcium ions are messengers associated with multiple pathways that play an important role in lymphocyte and tumor cells behavior and death [44,45]. According to the results of the present study, the surface roughness of the microarc $\mathrm{CaP}$ coating controlled Jurkat $\mathrm{T}$ cell cultures. However, due to prolonged and poor dissolution of the surface [40], $\mathrm{Ca}^{2+}$ may be only one of the effectors of influence of the microarc $\mathrm{CaP}$ coating in vitro. Microparticles (Figure 4$)$, as well as nanocrystallites $(\sim 50 \mathrm{~nm})$ of monetite $\left(\mathrm{CaHPO}_{4}\right)$ and calcium pyrophosphate $\left(\beta-\mathrm{Ca}_{2} \mathrm{P}_{2} \mathrm{O}_{7}\right)$, in microarc CaP coatings are capable of extracting [27] and mediating effects on cells. In particular, $\mathrm{CaP}$ nanoparticles are internalized and biodegraded by tumor cells [46]. Crystalline calcium pyrophosphate stimulates cell secretion of proinflammatory molecules [47], and pyrophosphate derivatives (bisphosphonates) inhibit tumor cell growth [48].

Surface topography also affects cells [49]. The influence of surface roughness/topography on cells [50] is studied more intensively than the effect of the electrostatic factor of rough dielectric surfaces [28]. However, the balance between the physical and chemical events that affect cell behavior is still unclear. 
The morphologies of slightly soluble microarc CaP coatings of different roughness were similar (Figure 1). Hence, the negative EP magnitude was directly dependent on the MAO voltage (Figure 5) and $R_{a}$ value of the microarc CaP surface [28]. Therefore, its biological significance was also suggested to regulate leukemic Jurkat $\mathrm{T}$ cells.

The large magnitude $(400-500 \mathrm{mV})$ of surface EP measured in air (Figure 5) is reduced in electrolytes [33] by the electrokinetic interaction at the artificial surface and solution interface and the formation of a double electric layer [51]. The microarc CaP coating in $\mathrm{KCl}$ aqueous solution possessed a negative charge with a zeta ( $\zeta$ ) potential of $63 \pm 1 \mathrm{mV}$, which was 3-fold below its EP measured in air $(-202 \pm 14 \mathrm{mV})$. No changes in $\zeta$-potential at $\mathrm{pH}$ values in the range of $5.5-8$ units at a temperature of $293 \mathrm{~K}$ were detected.

The $\zeta$-potential influences negatively charged Jurkat $\mathrm{T}$ cell attachment [19], and it is connected with transmembrane potential (TMP) [52]. Tumor cells possess depolarized TMP with a negative charge in the range of 5-50 $\mathrm{mV}$ compared with that of quiescent healthy cells that have more negative charges. The TMP is a key biophysical signal in nonexcitable cells that modulates cellular activities, including proliferation, differentiation, viability, and motility [53]. The external electric field impacts the TMP [54], and the reduced resting potential of cells facilitates their sensitivity to irritants. The $\zeta$-potential of the microarc CaP surface is comparable to the TMP of tumor cells and could promote their hyperpolarization or depolarization of the membrane, resulting in an intracellular $\left[\mathrm{Ca}^{2+}\right]$ increase via different types of channels [55].

There were no significant correlations between the adhesion force of negatively charged Jurkat $\mathrm{T}$ cells and the roughness of the $\mathrm{TiO}_{2}$ negative surface [19]. Regarding calcium release from microarc CaP-coated Ti samples, $\mathrm{Ca}^{2+}$ may enhance and prolong Jurkat $\mathrm{T}$ cell interactions with negative CaP surfaces (Figure 5) by diminishing electrostatic repulsion. Thereafter, TMP fluctuations during lymphocyte activation also depend on the gradient between the extracellular $\left[\mathrm{Ca}^{2+}\right](\sim 1 \mathrm{mM})$ and the intracellular $\left[\mathrm{Ca}^{2+}\right](\sim 0.1 \mu \mathrm{M})[45]$. In turn, the increasing extracellular Ca concentration $\left(1 \mathrm{mM} \mathrm{CaCl}_{2}\right)$ in the presence of ionomycin induces time-dependent transient changes in the intracellular Ca level and stimulates IL-2 secretion in human Jurkat T cells [44]. The $\zeta$-potential of microarc CaP coatings may promote $\mathrm{Ca}^{2+}$ influx by changing the resting potential of cells.

Thus, the roughness of the microarc CaP coating on Ti samples has at least two mediators, namely, the negative surface charge and Ca flux, that affect cells. Therefore, the current study showed no obvious effect of rough CaP-coated Ti samples on Jurkat $\mathrm{T}$ cell behavior, unlike the in vitro death of Jurkat $\mathrm{T}$ cells that were in short-term contact with a microarc rough $\mathrm{TiO}_{2}$ coating generating a negative surface charge. The $\mathrm{TiO}_{2}$ effect was accompanied by the downregulation of $h T E R T$ expression, $\mathrm{CD}$ presentation, and cytokine secretion by tumor cells [20].

In contrast, the short-term influence of the microarc rough CaP coating led to clear signs of hyperactivation-dependent death [39] in CD4 ${ }^{+}$leukemic cells expressing CD25 and CD95, which are markers of activation and apoptosis (Tables 2-4) possibly triggered by ex vivo irritants. Expression of the telomerase gene ( $h T E R T)$ is crucial for cell survival, and its expression is actively increased in proliferating Jurkat $\mathrm{T}$ cells [56] to promote cytokine secretion [57]. Indeed, a 1.7-fold upregulation in hTERT expression was observed in Jurkat $\mathrm{T}$ cells that were in contact with the CaP coating (Table 2) and was accompanied by an increased number of $\mathrm{CD} 45 \mathrm{R} 0^{+}$activated cells (Table 3 ) and enhanced chemokine secretion (Table 4).

To induce cell death, a sustained influx of extracellular $\mathrm{Ca}^{2+}$ and the presence of the death receptor Fas on the target cell have been shown to be required for FasL/Fas-mediated (CD95) cell injury [44]. Overall, increased $\left[\mathrm{Ca}^{2+}\right]$ in the cell nucleus is needed to initiate DNA fragmentation followed by cytolysis [58].

There have been a few reports about ARS staining of intracellular calcium ions, such as in [59]. However, ARS is widely used to analyze extracellular calcium salt deposition, and the difficulties of its uptake into cells are known [60]. Therefore, the results in Figure 6 suggest enhanced membrane permeability caused by Jurkat $T$ cell injury and associated cell death. Indeed, significant downregulation of $h T E R T$ expression, decreased cytokine and chemokine secretion, and enhanced expression of CD95, 
a marker of late activation/apoptosis, were detected on CD4 ${ }^{+}$Jurkat $\mathrm{T}$ cells after prolonged 14-day contact with microarc CaP coatings (Tables 2-4). Chemokines play a crucial role in the metastasis of malignant tumor cells [61] and Jurkat T cells [62]. In addition, VEGF secretion, which was connected with $\mathrm{Ca}^{2+}$ influx and promoted angiogenesis-associated tumor cell progression [63], was depleted by 1.5-6 times during the experimental period. At the same time, the CD4 ${ }^{+}$subset expanded from $62 \%$ to $78 \%$ of the cell population, and cell viability did not fall (Table 3 ).

Perhaps short-term 2-day culture with $\mathrm{CaP}$ induced hyperactivation-dependent death of CD4 ${ }^{+}$ Jurkat T cells, followed by a 14-day selection of the $h$ TERT-independent viable subsets (Tables 2 and 3 ). Reduced expression of the CD71 (Table 3) transferrin receptor stimulated Jurkat T cell proliferation and activation [64] was also noted. Moreover, the cytokine/chemokine network was decreased and included impaired mitotic/costimulatory/antiapoptotic signaling associated with IL-1, IL-4, IL-6, and IL-8 [65-69] (Table 4). Therefore, the molecular mechanisms underlying the 14-day survival of a portion of CD4 ${ }^{+}$ Jurkat $\mathrm{T}$ cells in the presence of rough and soluble CaP coating have not yet been clarified. Reduced biomolecule production is capable of limiting cytokine/chemokine-induced hyperactivation/death of Jurkat $\mathrm{T}$ cells and promoting their survival. The costimulatory cell surface antigen CD28 on Jurkat T cells [70] could be a molecular messenger of the described effect. From a cellular point of view, bone is thought to be a substrate for leukemic cell niches [71,72], and CaP bone minerals may affect the quiescent state of malignant cells.

Regardless, gene (hTERT) and secretory (17 of 27 tested biomolecules) hypoergy in tumor immune-competent $\mathrm{T}$ cells caused in vitro by long-term contact with microarc rough $\mathrm{CaP}$-coated $\mathrm{Ti}$ substrates may be useful for affecting their high progression and damage to bone regeneration after osteosynthesis. We believe that continuously reduced VEGF secretion (Table 4) correlated with the $R_{a}$ surface index is able to limit surgical stress-induced metastasis of hematopoietic malignancies. These findings need to be verified in inbred animals with spontaneous leukemia, e.g., the AKR line of mice.

Thus, the variable morphofunctional response of widely used Jurkat $\mathrm{T}$ cells cocultured with $\mathrm{CaP}$-coated samples should be considered when testing materials that are meant to have durable contact with the human body, especially in cancer patients. The main results are presented in Figure 7 . Therefore, many in vitro estimations of implant biological properties may change in long-term cell cultures.

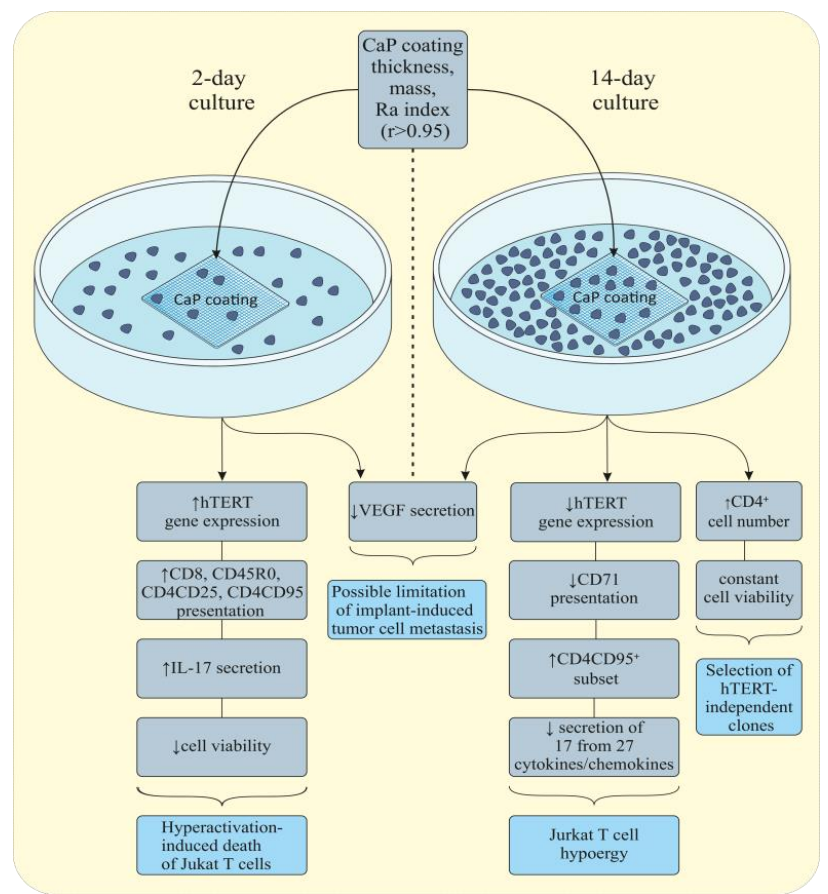

Figure 7. Variable reactions of Jurkat $\mathrm{T}$ cells induced by rough microarc CaP-coated titanium substrates in short-term and long-term cultures. 


\section{Conclusions}

This study showed voltage-dependent $(150-300 \mathrm{~V})$ growth of structural $\left(R_{a}\right.$ index, mass, and thickness) and morphological (spherulites, valleys, and pores) surface and volume elements, low calcium content $\left(\mathrm{Ca} / \mathrm{P}_{\mathrm{aT}}=0.3-0.6\right)$, the appearance of crystalline phases of $\mathrm{CaHPO}_{4}$ (monetite) and $\beta-\mathrm{Ca}_{2} \mathrm{P}_{2} \mathrm{O}_{7}$ (calcium pyrophosphate), and an increased magnitude of negative electrostatic voltage in the $\mathrm{CaP}$ coatings deposited via MAO on Ti substrate. Strong correlations were identified between technological parameters ( $R_{a}$, thickness, and mass values), as well as between the index $R_{a}=2-5 \mu \mathrm{m}$ and the cellular and molecular behavior of Jurkat $\mathrm{T}$ cells cultured in vitro.

Because of the close relations of $R_{a}$ indices to cytological properties, we distinguished the surface roughness of the microarc $\mathrm{CaP}$ coating as a trigger of hyperactivation-dependent death in $\mathrm{CD} 4^{+}$ cells in 2-day cultures, followed by the selection of $h T E R T$-independent viable subsets of Jurkat $\mathrm{T}$ cells combined with significant secretory (17 of 27 cytokines/chemokines, including VEGF) and proliferation gene ( $h T E R T)$ hypoergy after prolonged 14-day contact with test samples. Negative $\zeta$-potential and $\mathrm{Ca}^{2+}$ could mediate the biological effects of $\mathrm{CaP}$ roughness on cell reactions. Impaired mitotic/costimulatory/antiapoptotic signaling of CD71, IL-1, IL-4, IL-6, IL-8, and other chemokines induced by $\mathrm{CaP}$ coatings might affect the prolonged survival of Jurkat $\mathrm{T}$ cells with downregulated hTERT expression. At the same time, the molecular mechanisms underlying the 14-day selection of a portion of $\mathrm{CD}^{+}$Jurkat $\mathrm{T}$ cells in the long-term presence of rough and soluble CaP coating can be further explored.

In summary, reduced chemokine and VEGF secretion by malignant cells correlated with the $R_{a}$ roughness index of microarc $\mathrm{CaP}$ coating is an effective competitive advantage that may distinguish this material for endoprosthetics and osteosynthesis in patients suffering from lymphoid leukemia.

Author Contributions: Conceptualization, L.S.L., O.G.K., E.G.K. and I.A.K.; Data curation, K.A.Y.; Funding acquisition, P.A.I.; Investigation, O.G.K., V.V.S., K.A.Y., E.G.K. and V.V.C.; Project administration, L.S.L.; Software, V.V.M.; Supervision, I.A.K.; Validation, P.A.I., E.G.K. and E.A.G.; Visualization, E.O.S. and E.D.P.; Writing-original draft, L.S.L., E.G.K., E.A.G. and I.A.K.; Writing-review \& editing, E.G.K. and I.A.K. All authors have read and agreed to the published version of the manuscript.

Funding: This research was funded by the Russian Science Foundation (Project No. 16-15-10031).

Acknowledgments: The authors thank Yurii P. Sharkeev (ISPMS SB RAS, Tomsk, Russia) for fruitful discussions and helping to prepare this article for submission and Marina V. Chaikina (Institute of Solid-State Chemistry and Mechanochemistry SB RAS, Novosibirsk, Russia) for production of the hydroxyapatite.

Conflicts of Interest: The authors declare no conflict of interest.

\section{References}

1. Habraken, W.; Habibovic, P.; Epple, M.; Bohner, M. Calcium phosphates in biomedical applications: Materials for the future? Mater. Today 2016, 19, 69-87. [CrossRef]

2. Moroni, A.; Vannini, F.; Mosca, M.; Giannini, S. State of the art review: Techniques to avoid pin loosening and infection in external fixation. J. Orthop. Trauma 2002, 16, 189-195. [CrossRef] [PubMed]

3. Walsh, F.C.; Low, C.T.J.; Wood, R.J.K.; Stevens, K.T.; Archer, J.; Poeton, A.R.; Ryder, A. Plasma electrolytic oxidation (PEO) for production of anodised coatings on lightweight metal (Al, Mg, Ti) alloys. Trans. IMF 2009, 87, 122-135. [CrossRef]

4. Krząkała, A.; Kazek-Kęsik, A.; Simka, W. Application of plasma electrolytic oxidation to bioactive surface formation on titanium and its alloys. RSC Adv. 2013, 3, 19725. [CrossRef]

5. Sedelnikova, M.B.; Komarova, E.G.; Sharkeev, Y.P.; Tolkacheva, T.V.; Khlusov, I.A.; Litvinova, L.S.; Yurova, K.A.; Shupletsova, V.V. Comparative investigations of structure and properties of micro-arc wollastonite-calcium phosphate coatings on titanium and zirconium-niobium alloy. Bioact. Mater. 2017, 2, 177-184. [CrossRef]

6. Qadir, M.; Li, Y.; Munir, K.; Wen, C. Calcium phosphate-based composite coating by micro-arc oxidation (MAO) for biomedical application: A review. Crit. Rev. Solid State Mater. Sci. 2018, 43, 392-416. [CrossRef] 
7. Khlusov, I.A.; Shevtsova, N.M.; Khlusova, M.Y. Detection in vitro and quantitative estimation of artificial microterritories which promote osteogenic differentiation and maturation of stromal stem cells. Methods Mol. Biol. 2013, 1035, 103-119. [CrossRef]

8. Fillingham, Y.A.; Cvetanovich, G.L.; Haughom, B.D.; Erickson, B.J.; Gitelis, S. Bioceramic bone graft substitute for treatment of unicameral bone cysts. J. Orthop. Surg. 2016, 24, 222-227. [CrossRef]

9. Shi, Y.; Su, Z.; Li, S.; Chen, Y.; Chen, X.; Xiao, Y.; Sun, M.; Ping, Q.; Zong, L. Multistep targeted nano drug delivery system aiming at leukemic stem cells and minimal residual disease. Mol. Pharm. 2013, 10, 2479-2489. [CrossRef]

10. Corre, J.; Mahtouk, K.; Attal, M.; Gadelorge, M.; Huynh, A.; Fleury-Cappellesso, S.; Danho, C.; Laharrague, P.; Klein, B.; Rème, T.; et al. Bone marrow mesenchymal stem cells are abnormal in multiple myeloma. Leukemia 2007, 21, 1079-1088. [CrossRef]

11. Aveic, S.; Davtalab, R.; Vogt, M.; Weber, M.; Buttler, P.; Tonini, G.P.; Fischer, H. Calcium phosphate scaffolds with defined interconnecting channel structure provide a mimetic 3D niche for bone marrow metastasized tumor cell growth. Acta Biomater. 2019, 88, 527-539. [CrossRef] [PubMed]

12. Asghar, W.; El Assal, R.; Shafiee, H.; Pitteri, S.; Paulmurugan, R.; Demirci, U. Engineering cancer microenvironments for in vitro 3-D tumor models. Mater. Today 2015, 18, 539-553. [CrossRef]

13. Clara-Trujillo, S.; Ferrer, G.G.; Ribelles, J.L.G. In vitro modeling of non-solid tumors: How far can tissue engineering go? Int. J. Mol. Sci. 2020, 21, 5747. [CrossRef] [PubMed]

14. Li, D.; Lin, T.L.; Lipe, B.; Hopkins, R.A.; Shinogle,H.; Aljitawi, O.S. A novel extracellular matrix-basedleukemia model supports leukemia cells with stem cell-like characteristics. Leuk. Res. 2018, 72, 105-112. [CrossRef] [PubMed]

15. Blanco, T.M.; Mantalaris, A.; Bismarck, A.; Panoskaltsis, N. The development of a three-dimensional scaffold for ex vivo biomimicry of human acute myeloid leukaemia. Biomaterials 2010, 31, 2243-2251. [CrossRef] [PubMed]

16. Abarrategi, A.; Mian, S.A.; Passaro, D.; Rouault-Pierre, K.; Grey, W.; Bonnet, D. Modeling the human bone marrow niche in mice: From host bone marrow engraftment to bioengineering approaches. J. Exp. Med. 2018, 215, 729-743. [CrossRef]

17. Groen, R.W.; Noort, W.A.; Raymakers, R.A.; Prins, H.J.; Aalders, L.; Hofhuis, F.M.; Moerer, P.; van Velzen, J.F.; Bloem, A.C.; van Kessel, B.; et al. Reconstructing the human hematopoietic niche in immunodeficient mice: Opportunities for studying primary multiple myeloma. Blood 2012, 120, e9-e16. [CrossRef]

18. Zinger, O.; Zhao, G.; Schwartz, Z.; Simpson, J.; Wieland, M.; Landolt, D.; Boyan, B. Differential regulation of osteoblasts by substrate microstructural features. Biomaterials 2005, 26, 1837-1847. [CrossRef]

19. Stevens, M.J.; Donato, L.J.; Lower, S.K.; Sahai, N. Oxide-dependent adhesion of the Jurkat line of T lymphocytes. Langmuir 2009, 25, 6270-6278. [CrossRef]

20. Khlusov, I.; Litvinova, L.; Shupletsova, V.; Khaziakhmatova, O.; Melashchenko, E.; Yurova, K.; Leitsin, V.; Khlusova, M.; Pichugin, V.; Sharkeev, Y. Rough titanium oxide coating prepared by micro-arc oxidation causes down-regulation of $h T E R T$ expression, molecular presentation, and cytokine secretion in tumor Jurkat T cells. Materials 2018, 11, 360. [CrossRef]

21. Abraham, R.T.; Weiss, A. Jurkat T cells and development of the T-cell receptor signaling paradigm. Nat. Rev. Immunol. 2004, 4, 301-308. [CrossRef] [PubMed]

22. Wiskocil, R.; Weiss, A.; Imboden, J.; Kamin-Lewis, R.; Stobo, J. Activation of a human T cell line: A two-stimulus requirement in the pretranslational events involved in the coordinate expression of interleukin 2 and $\gamma$-interferon genes. J. Immunol. 1985, 134, 1599-1603. [PubMed]

23. Polacheck, W.J.; Zervantonakis, I.K.; Kamm, R.D. Tumor cell migration in complex microenvironments. Cell. Mol. Life Sci. 2013, 70, 1335-1356. [CrossRef]

24. Tuomela, S.; Autio, R.; Buerki-Thurnherr, T.; Arslan, O.; Kunzmann, A.; Andersson-Willman, B.; Wick, P.; Mathur, S.; Scheynius, A.; Krug, H.F.; et al. Gene expression profiling of immune-competent human cells exposed to engineered zinc oxide or titanium dioxide nanoparticles. PLoS ONE 2013, 8, e68415. [CrossRef] [PubMed]

25. Yuan, Y.; Lu, X.; Chen, X.; Shao, H.; Huang, S. Jagged1 contributes to the drug resistance of Jurkat cells in contact with human umbilical cord-derived mesenchymal stem cells. Oncol Lett. 2013, 6, 1000-1006. [CrossRef] 
26. Ermis, M.; Akkaynak, D.; Chen, P.; Demirci, U.; Hasirci, V. A high throughput approach for analysis of cell nuclear deformability at single cell level. Sci. Rep. 2016, 6, 36917. [CrossRef]

27. Sedelnikova, M.B.; Komarova, E.G.; Sharkeev, Y.P.; Ugodchikova, A.V.; Mushtovatova, L.S.; Karpova, M.R.; Sheikin, V.V.; Litvinova, L.S.; Khlusov, I.A. Zn-, Cu- or Ag-incorporated micro-arc coatings on titanium alloys: Properties and behavior in synthetic biological media. Surf. Coat. Tech. 2019, 369, 52-68. [CrossRef]

28. Khlusov, I.A.; Dekhtyar, Y.; Sharkeev, Y.P.; Pichugin, V.F.; Khlusova, M.Y.; Polyaka, N.; Tjulkins, F.; Vendinya, V.; Legostaeva, E.V.; Litvinova, L.S.; et al. Nanoscale electrical potential and roughness of a calcium phosphate surface promotes the osteogenic phenotype of stromal cells. Materials 2018, 11, 978. [CrossRef]

29. Chaikina, M.V.; Bulina, N.V.; Ishchenko, A.V.; Prosanov, I.Y. Mechanochemical synthesis of $\mathrm{SiO}_{4}{ }^{4-}{ }^{-}$substituted hydroxyapatite. Part I-Kinetics of interaction between the components. Eur. J. Inorg. Chem. 2014, 2014, 4803-4809. [CrossRef]

30. Komarova, E.G.; Sedelnikova, M.B.; Kondranova, A.M.; Kazantsev, S.O.; Sharkeev, Y.P. Development of calcium phosphate coatings with regulated porous structure as drug carrier systems. J. Phys. Conf. Ser. 2019, 1281, 012037. [CrossRef]

31. Gadelmawla, E.S.; Koura, M.M.; Maksoud, T.M.A.; Elewa, I.M.; Soliman, H.H. Roughness parameters. J. Mater. Process. Tech. 2002, 123, 133-145. [CrossRef]

32. Eguchi, M. On the permanent electret. Philos. Mag. 1925, 49, 178-192. [CrossRef]

33. Pichugin, V.F.; Pustovalova, A.A.; Konishchev, M.E.; Khlusov, I.A.; Ivanova, N.M.; Zhilei, S.; Gutor, S.S. In-vitro dissolution and structural and electrokinetic characteristics of titanium-oxynitride coatings formed via reactive magnetron sputtering. J. Surf. Investig. 2016, 10, 282-291. [CrossRef]

34. Banda, M.; Bommineni, A.; Thomas, R.A.; Luckinbill, L.S.; Tucker, J.D. Evaluation and validation of housekeeping genes in response to ionizing radiation and chemical exposure for normalizing RNA expression in real-time PCR. Mutat. Res. 2008, 649, 126-134. [CrossRef]

35. Chan, L.L.-Y.; Kuksin, D.; Laverty, D.J.; Saldi, S.; Qiu, J. Morphological observation and analysis using automated image cytometry for the comparison of trypan blue and fluorescence-based viability detection method. Cytotechnology 2015, 67, 461-473. [CrossRef] [PubMed]

36. Narayanan, T.S.N.S.; Park, I.S.; Lee, M.H. Strategies to improve the corrosion resistance of microarc oxidation (MAO) coated magnesium alloys for degradable implants: Prospects and challenges. Prog. Mater. Sci. 2014, 60, 1-71. [CrossRef]

37. Wang, Y.; Yu, H.; Chen, C.; Zhao, Z. Review of the biocompatibility of micro-arc oxidation coated titanium alloys. Mater. Des. 2015, 85, 640-652. [CrossRef]

38. van den Broek, L.J.; Kroeze, K.L.; Waaijman, T.; Breetveld, M.; Sampat-Sardjoepersad, S.C.; Niessen, F.B.; Middelkoop, E.; Scheper, R.J.; Gibbs, S. Differential response of human adipose tissue-derived mesenchymal stem cells, dermal fibroblasts, and keratinocytes to burn wound exudates: Potential role of skin-specific chemokine CCL27. Tissue Eng. Part A 2014, 20, 197-209. [CrossRef]

39. Massanella, M.; Negredo, E.; Pérez-Alvarez, N.; Puig, J.; Ruiz-Hernández, R.; Bofill, M.; Clotet, B.; Blanco, J. CD4 T-cell hyperactivation and susceptibility to cell death determine poor CD4 T-cell recovery during suppressive HAART. AIDS 2010, 24, 959-968. [CrossRef] [PubMed]

40. Litvinova, L.S.; Shupletsova, V.V.; Yurova, K.A.; Khaziakhmatova, O.G.; Todosenko, N.M.; Khlusova, M.Y.; Slepchenko, G.B.; Cherempey, E.G.; Sharkeev, Y.P.; Komarova, E.G.; et al. Cell-IQ Visualization of motility, cell mass, and osteogenic differentiation of multipotent mesenchymal stromal cells cultured with relief calcium phosphate coating. Dokl. Biochem. Biophys. 2017, 476, 310-315. [CrossRef]

41. Zayzafoon, M. Calcium/calmodulin signaling controls osteoblast growth and differentiation. J. Cell. Biochem. 2006, 97, 56-70. [CrossRef] [PubMed]

42. Chai, Y.C.; Carlier, A.; Bolander, J.; Roberts, S.J.; Geris, L.; Schrooten, J.; Van Oosterwyck, H.; Luyten, F.P. Current views on calcium phosphate osteogenicity and the translation into effective bone regeneration strategies. Acta Biomater. 2012, 8, 3876-3887. [CrossRef] [PubMed]

43. Yanai, R.; Tetsuo, F.; Ito, S.; Itsumi, M.; Yoshizumi, J.; Maki, T.; Mori, Y.; Kubota, Y.; Kajioka, S. Extracellular calcium stimulates osteogenic differentiation of human adipose-derived stem cells by enhancing bone morphogenetic protein-2 expression. Cell Calcium 2019, 83, 102058. [CrossRef] [PubMed]

44. Podszywalow-Bartnicka, P.; Strzelecka-Kiliszek, A.; Bandorowicz-Pikula, J.; Pikula, S. Calcium-and proton-dependent relocation of annexin A6 in Jurkat T cells stimulated for interleukin-2 secretion. Acta Biochim. Pol. 2007, 54, 261-271. [CrossRef] [PubMed] 
45. Bose, T.; Cieślar-Pobuda, A.; Wiechec, E. Role of ion channels in regulating $\mathrm{Ca}^{2+}$ homeostasis during the interplay between immune and cancer cells. Cell Death Dis. 2015, 6, e1648. [CrossRef]

46. Khalifehzadeh, R.; Arami, H. Biodegradable calcium phosphate nanoparticles for cancer therapy. Adv. Colloid Interface Sci. 2020, 279, 102157. [CrossRef]

47. Felicity, C.; Edwards, F.C.; Taheri, A.; Dann, S.C.; Dye, J.F. Characterization of cytolytic neutrophil activation in vitro by amorphous hydrated calcium phosphate as a model of biomaterial inflammation. J. Biomed. Mater. Res. A 2011, 96, 552-565. [CrossRef]

48. Ural, A.U.; Yilmaz, M.I.; Avcu, F.; Pekel, A.; Zerman, M.; Nevruz, O.; Sengul, A.; Yalcin, A. The bisphosphonate zoledronic acid induces cytotoxicity in human myeloma cell lines with enhancing effects of dexamethasone and thalidomide. Int. J. Hematol. 2003, 78, 443-449. [CrossRef]

49. Curtis, A.; Wilkinson, C. Topographical control of cells. Biomaterials 1997, 18, 1573-1583. [CrossRef]

50. Martínez, E.; Engel, E.; Planell, J.A.; Samitier, J. Effects of artificial micro- and nano-structured surfaces on cell behaviour. Ann. Anat. Anat. Anz. 2009, 191, 126-135. [CrossRef]

51. Xie, H.; Saito, T.; Hickner, M.A. Zeta potential of ion-conductive membranes by streaming current measurements. Langmuir 2011, 27, 4721-4727. [CrossRef] [PubMed]

52. Adak, S.; Chowdhury, S.; Bhattacharyya, M. Dynamic and electrokinetic behavior of erythrocyte membrane in diabetes mellitus and diabetic cardiovascular disease. Biochim. Biophys. Acta 2008, 1780, 108-115. [CrossRef]

53. Yang, M.; Brackenbury, W.J. Membrane potential and cancer progression. Front. Physiol. 2013, 4, 185. [CrossRef] [PubMed]

54. Levin, M. Bioelectromagnetics in morphogenesis. Bioelectromagnetics 2003, 24, 295-315. [CrossRef] [PubMed]

55. Schwab, A.; Fabian, A.; Hanley, P.J.; Stock, C. Role of ion channels and transporters in cell migration. Physiol. Rev. 2012, 92, 1865-1913. [CrossRef]

56. Lin, Z.; Lim, S.; Viani, M.A.; Sapp, M.; Lim, M.S. Down-regulation of telomerase activity in malignant lymphomas by radiation and chemotherapeutic agents. Am. J. Pathol. 2001, 159, 711-719. [CrossRef]

57. Kanzaki, Y.; Onoue, F.; Sakurai, H.; Ide, T. Telomerase upregulates expression levels of interleukin (IL)-1alpha, IL-1beta, IL-6, IL-8, and granulocyte-macrophage colony-stimulating factor in normal human fibroblasts. Biochem. Biophys. Res. Commun. 2003, 305, 150-154. [CrossRef]

58. Trump, B.E.; Berezesky, I.K. The role of cytosolic $\mathrm{Ca}^{2+}$ in cell injury, necrosis and apoptosis. Curr. Opin. Cell Biol. 1992, 4, 227-232. [CrossRef]

59. Chen, D.; Zhao, J.; Zhang, L.; Liu, R.; Huang, Y.; Lan, C.; Zhao, S. Capsicum-derived biomass quantum dots coupled with alizarin Red S as an inner-filter-mediated illuminant nanosystem for imaging of intracellular calcium ions. Anal. Chem. 2018, 90, 13059-13064. [CrossRef]

60. Puchtler, H.; Meloan, S.N.; Terry, M.S. On the history and mechanism of alizarin and alizarin red S stains for calcium. J. Histochem. Cytochem. 1969, 17, 110-124. [CrossRef]

61. Murphy, P.M. Chemokines and the molecular basis of cancer metastasis. N. Engl. J. Med. 2001, 345, 833-835. [CrossRef] [PubMed]

62. Gao, P.; Wange, R.L.; Zhang, N.; Oppenheim, J.J.; Howard, O.M.Z. Negative regulation of CXCR4-mediated chemotaxis by the lipid phosphatase activity of tumor suppressor PTEN. Blood 2005, 106, 2619-2626. [CrossRef] [PubMed]

63. Yang, S.; Zhang, J.J.; Huang, X.Y. Orai1 and STIM1 are critical for breast tumor cell migration and metastasis. Cancer Cell 2009, 15, 124-134. [CrossRef] [PubMed]

64. Batista, A.; Millan, J.; Mittelbrunn, M.; Sanchez-Madrid, F.; Alonso, M.A. Recruitment of transferrin receptor to immunological synapse in response to TCR engagement. J. Immunol. 2004, 172, 6709-6714. [CrossRef] [PubMed]

65. Arana-Argáez, V.E.; Delgado-Rizo, V.; Pizano-Martínez, O.E.; Martínez-Garcia, E.A.; Martín-Márquez, B.T.; Muñoz-Gómez, A.; Petri, M.H.; Armendáriz-Borunda, J.; Espinosa-Ramírez, G.; Zúñiga-Tamayo, D.A.; et al. Inhibitors of MAPK pathway ERK1/2 or p38 prevent the IL-1\{beta\}-induced up-regulation of SRP72 autoantigen in Jurkat cells. J. Biol. Chem. 2010, 285, 32824-32833. [CrossRef]

66. Jang, J.-Y.; Lee, C.-E. IL-4-induced upregulation of adenine nucleotide translocase 3 and its role in Th cell survival from apoptosis. Cell Immunol. 2006, 241, 14-25. [CrossRef]

67. Tatsuta, T.; Cheng, J.; Mountz, J.D. Intracellular IL-1beta is an inhibitor of Fas-mediated apoptosis. J. Immunol. 1996, 157, 3949-3957. 
68. Law, H.K.W.; Tu, W.; Liu, E.; Lau, Y.L. Insulin-like growth factor I promotes cord blood T cell maturation through monocytes and inhibits their apoptosis in part through interleukin-6. BMC Immunol. 2008, 9, 74. [CrossRef]

69. Waugh, D.J.J.; Wilson, C. The interleukin-8 pathway in cancer. Clin. Cancer Res. 2008, 14, 6735-6741. [CrossRef]

70. Li-Weber, M.; Giasi, M.; Krammer, P.H. Involvement of Jun and Rel proteins in up-regulation of interleukin-4 gene activity by the T cell accessory molecule CD28. J. Biol. Chem. 1998, 273, 32460-32466. [CrossRef]

71. Colmone, A.; Amorim, M.; Pontier, A.L.; Wang, S.; Jablonski, E.; Sipkins, D.A. Leukemic cells create bone marrow niches that disrupt the behavior of normal hematopoietic progenitor cells. Science 2008, 322, 1861-1865. [CrossRef] [PubMed]

72. Le, P.M.; Andreeff, M.; Battula, V.L. Osteogenic niche in the regulation of normal hematopoiesis and leukemogenesis. Haematologica 2018, 103, 1945-1955. [CrossRef] [PubMed]

(C) 2020 by the authors. Licensee MDPI, Basel, Switzerland. This article is an open access article distributed under the terms and conditions of the Creative Commons Attribution (CC BY) license (http://creativecommons.org/licenses/by/4.0/). 